\title{
СВЯТИЛИЩЕ С ЧЕЛОВЕЧЕСКИМИ ОСТАНКАМИ В ПЕЩЕРЕ ШУЛЬГАН-ТАШ (КАПОВОЙ)
}

\section{Котов Вячеслав Георгиевич}

Институт истории, языка и литературы УФИЦ РАН, Уфа, Россия

E-mail: kslav1@yandex.ru

Савельев Никита Сергеевич

\author{
Институт истории, языка и литературы УФИЦ РАН, Уфа, Россия \\ E-mail: sns_1971@mail.ru
}

\begin{abstract}
Аннотация. В ходе археологических исследований последних двух десятилетий в Купольном и Сталагмитовом залах пещеры Шульган-Таш (Каповой) были сделаны многочисленные находки человеческих останков, в основном представленных целыми и фрагментированными черепами. Вместе с ними были найдены кости животных, скопления углей, а также фрагменты керамики завершающего этапа эпохи бронзы. Установлено, что в Сталагмитовом зале существовало святилище, связанное с манипуляциями с человеческими останками (в основном - черепами и их фрагментами). Определено несколько ритуальных стратегий в отношении человеческих останков: выставление целых черепов, фрагментация черепов, скальпирование и очищение от мягких тканей, использование фрагментов черепной крышки в ритуальных трапезах. Семантика этих операций характерна для обрядов жертвоприношения и посвящения-инициации. Они находят объяснения в ритуалах человеческих жертвоприношений Матери-Земле и Хозяину нижнего мира - хану Шульгану, приуроченных к озеру-роднику Шульган и пещере ШульганТаш, упоминаемых в архаических башкирских эпосах и преданиях. Это позволяет сопоставить теоретические реконструкции по семантике обрядности населения финала бронзового века и раннего железа с мифологией древнего уральского населения.
\end{abstract}

Ключевые слова: Южный Урал, пещерное святилище, человеческие останки, выставления черепов, «избушка Бабы-Яги», семантика ритуала

Цитирование. Котов В.Г., Савельев Н.С., 2021. Святилище с человеческими останками в пещере Шульган-Таш (Каповой) // Уфимский археологический вестник. Т. 21, №2. С. 239-263. DOI: https://doi. org/10.31833/uav/2021.21.2.005

UDC 903.5(470.5)«638»

LBC 63.442(235.55)

Submitted: 30.09 .2021

Accepted: 20.10.2021

\author{
SANCTUARY WITH HUMAN SKELETAL REMAINS \\ IN THE SHULGAN-TASH (KAPOVA) CAVE \\ Vyacheslav G. Kotov \\ Institute of History, Language and Literature, UFRC RAS, Ufa, Russia \\ E-mail: kslav1@yandex.ru \\ Nikita S. Savelev \\ Institute of History, Language and Literature, UFRC RAS, Ufa, Russia \\ E-mail: sns_1971@mail.ru
}

\begin{abstract}
The Shulgan-Tash (Kapova) cave is famous for its rock paintings of the Upper Paleolithic period. However, no less important are the finds of human skulls dated to the Holocene era, which were discovered more than 250 years ago at the back of the cave. The archaeological studies of recent two decades at the Dome and Stalagmite halls of the cave resulted in numerous discoveries of human skeletal remains, represented mostly by whole and fragmented skulls. Those skulls were found together with animal bones, charcoal and pottery fragments of the Mezhovskaya culture of the late Bronze Age. Archaeological data suggests that human skeletal remains (skulls and their fragments) were used in rituals, which took place at the sanctuary located in the Stalagmite hall of the cave. In course of those rituals whole skulls were deliberately carved and exhibited around the sanctuary. Probably, this skull damaging symbolized a ritual killing. Some skulls were fragmented, human and animal bones were tucked in clefts and under the walls of the niche and fragments of skull roofs were used in ritualistic meals. We suppose that the aforementioned rituals were carried out as a part of the initiation rite. It is also possible that they accompanied human sacrifices for Mother Earth or Khan Shulgan (the god of the underworld) devoted to spring lake Shulgan and the Shulgan-Tash cave, which are mentioned in Bashkir epics and legends. This allow us to compare the theoretical reconstructions on the semantics of the rituals of the Late Bronze Age and the Early Iron Age with the mythology of the ancient Ural peoples.
\end{abstract}

Keywords: Southern Urals, cave sanctuary, human skeletal remains, skulls exhibiting, «Baba Yaga's hut», semantics of the ritual

Citation. Kotov V., Savelev N., 2021. Sanctuary with human skeletal remains in the Shulgan-Tash (Kapova) cave. Ufimskij arkheologicheskiy vestnik [The Ufa Archaeological Herald]. Vol.21, no.2, pp.000-000. (In Russ.). DOI: https://doi.org/10.31833/uav/2021.21.2.005 


\section{Введение}

ПещераШульган-Таш(Каповая)вгорно-лесной зоне Башкирии является одной из крупнейших пещер Южного Урала (рис. 1) и представляет собой двухуровневую систему, образованную крупными полостями с подземными озерами, воронками и ручьями. Общая длина ее разведанных ходов составляет около 3 км [Ляхницкий, 2006. С. 338]. Важнейшей особенностью пещеры является глубокое озеро-родник под огромной входной аркой - место выхода на поверхность р. Шульган (т.н. Подземный Шульган), исчезающей в глубокой воронке в 3,5 км выше по суходолу, на высоком плато правого берега р.Белая (рис.2). Все это с
Памяти М.Ф. Обыденнова - основного исследователя межовской культуры, долгие годы работавшего в горах Южного Урала

древности было причиной особого отношения к пещере, которая не могла не восприниматься как идеальное воплощение потустороннего мира [Щелинский, 1997.С. 29]. Об этом свидетельствуют и многочисленные предания и эпосы местного населения. Не случайно свое название пещера, гора, подземная река и озеро у входа получили от имени хозяина подземного мира башкирских эпосов хана Шульгана [Котов, 2006]. С пещерой и озером Шульган связан древнейший цикл эпосов и архаическая мифология, свидетельствуя о том, что пещера с глубокой древности являлась святилищем и мифологическим центром Южного Урала [Котов, 2010a].

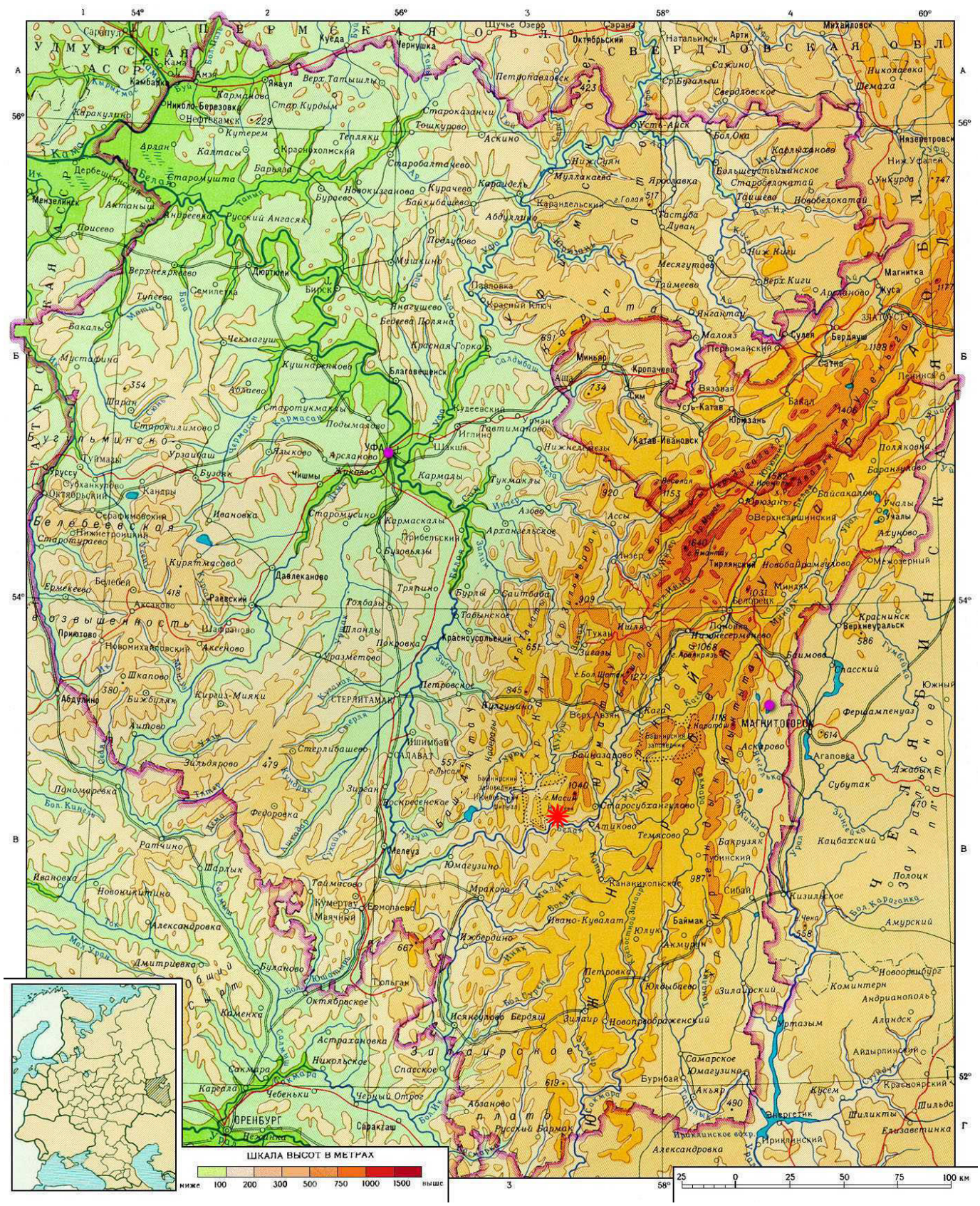

Рис. 1. Южный Урал. Положение пещеры Шульган-Таш (Каповая). Показано красной звездочкой Fig. 1. Southern Urals. Shulgan-Tash (Kapova) cave. Marked with a red asterisk 


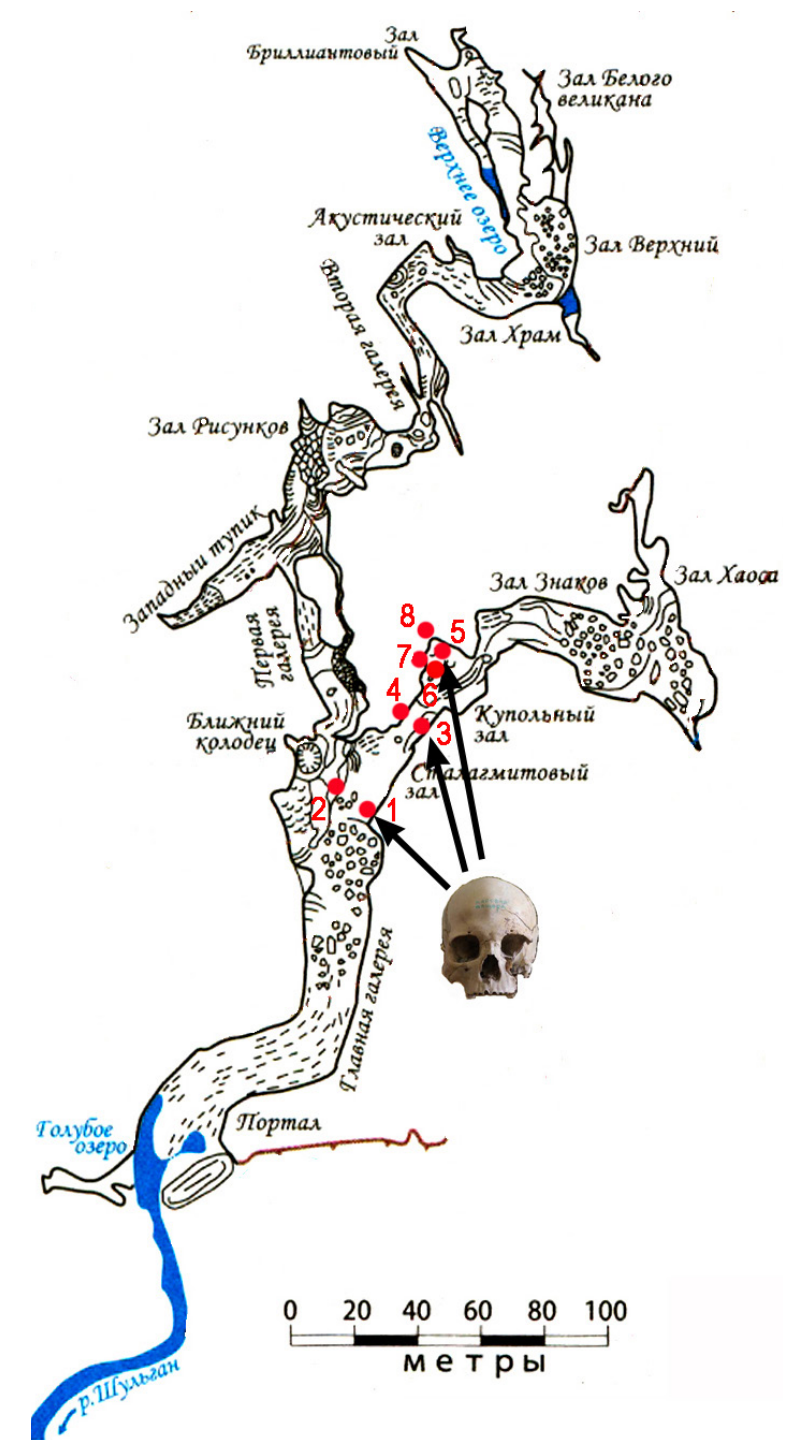

Рис.2. Пещера Шульган-Таш (Каповая), план «Старого отдела» (по: [Ляхницкий, 2006] с добавлениями В.Г.Котова). Места находок человеческих останков. Сталагмитовый зал: 1 - череп, найденный в 1896 г;; 2 - находки 2015 г. 3 - череп из Низкого перехода. Купольный зал: 4 - находки 1995 г; 5 - череп из Капеллы Черепов; 6, 7 - фрагменты черепов из Капеллы Черепов; 8 - скопление в расщелине Капеллы Черепов

Fig. 2. Shulgan-Tash (Kapova) cave, plan of the «Old Department» (after: [Lyakhnitsky, 2006] with additions by V.G.Kotov). Locations of human skeletal remains. Stalagmite hall: 1 - skull found in 1896; 2 - finds of 2015; 3 - skull from the Low passage. Dome hall: 4 - finds of 1995; 5 - skull from the Skull Chapel; 6, 7 - skull fragments from the Skull Chapel; 8 - assemblage in the cleft of the Skull Chapel

Хорошо известно, что пещера ШульганТаш (Каповая) являлась святилищем в эпоху верхнего палеолита, о чем говорят наскальные рисунки и другие находки в дальних залах пещеры [Бадер, 1965; Ščelinsij, Širokov, 1999; Котов, 2016; Житенев, 2017]. Между тем, находки других эпох также свидетельствуют о длительности почитания пещеры и осуществления в ней ритуальной деятельности. Среди них видное место занимают костные останки человека, обнаруженные в дальних залах пещерной полости, вне доступа дневного освещения - в залах Купольном и Сталагмитовом.

Расположенный в узком скальном ущелье вход в пещеру имеет форму арки шириной около 30 м и высотой 15 м. Еще большую таинственность пещере придает озеро-воклюз Шульган (Голубое) под аркой входа, соединяющийся ручьем с круглой воронкой, заполненной водой. Водой насыщен и грунт в начале Главной галереи, создавая вместе с озером и воронкой естественную водную преграду. На протяжении примерно 40 м пещера имеет северо-западное простирание. Далее Главная галерея поворачивает на север и тянется на расстоянии 70 м. Эта часть пещеры уже не освещена, свет лишь слабо попадает на ее восточную стену. В разные годы в освещенной части пещеры экспедицией ИИЯЛ УФИЦ РАН были собраны сотни расколотых костей животных плейстоценовой и голоценовой сохранности (лошадь, крупный и мелкий рогатый скот, кабан/свинья, олень, косуля), но костей человека среди них обнаружено не было [Котов, 2017; 2019; 2021].

С середины ориентированного на север участка Главной галереи пол повышается и у ее окончания лежат самые крупные глыбы, а далее расположены два первых зала - Сталагмитовый и Купольный, в которых и сделаны все известные к настоящему времени в пещере находки костей человека. К ним относятся 3 целых и 11 фрагментов черепов, а также два скопления костей с фрагментами черепов и посткраниального скелета. При дальнейшем описании всем находкам присвоен порядковый номер.

\section{Человеческие останки \\ в Сталагмитовом зале}

Следующее за Главной галереей отделение пещеры - зал Сталагмитовый. Он имеет северовосточное простирание, ширину около 17 м, длину 25-27 м и высоту до 16 м. Пол зала глинистый, относительно ровный и относительно сухой, расположен на высоте 11 м от современного уреза воды в р.Белая. Зал полностью темный, расстояние от входа в пещеру составляет 120 м (рис. 2). В нем зафиксировано две находки черепов человека.

Yepen № 1 найден лесником Ф.Гусевым в 1895 г. и передан им в Оренбургский отдел Императорского географического общества. В марте 1896г. сюда выехали члены географического общества Д.Соколов, И.Заневский и Ф.Симон. Они так описывают место этой находки: в углу какой-то ниши первого зала (Сталагмитового) перед Низким переходом в другой зал (Купольный) [Coколов и др., 1897. С. 77]. В настоящее время мы не располагаем данными о месте хранения черепа. На плане нижнего этажа пещеры, составленном под руководством Ф.П.Симона, место находки черепа было специально указано буквами «Ch», оно находилось между последней крупной глыбой и правой стеной [Соколов и др., 1897. С. 77] (рис. 3).

\footnotetext{
${ }^{1}$ После революции половина фондов оренбургских музеев и библиотек была передана в г. Алма-Ата (совр. г. Алматы, Республика Казахстан).
} 


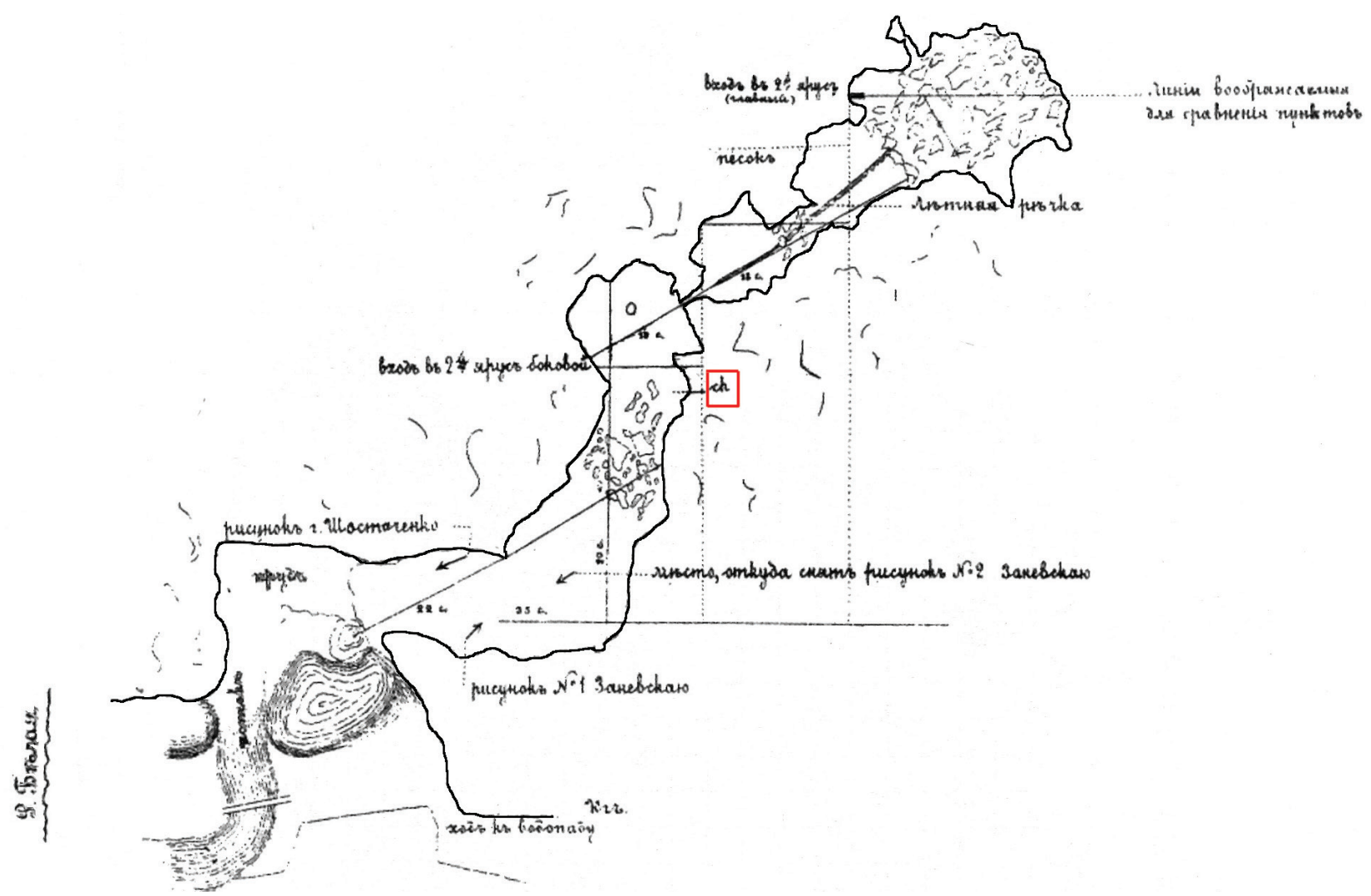

Рис. 3. План среднего этажа пещеры Шульган-Таш (Каповой), составленный Ф.П. Симоном, Д.Н. Соколовым и И. Заневским в 1896 г. (по: [Соколов и др., 1897])

Fig. 3. Plan of the middle floor of the Shulgan-Tash cave, drawn up by F. Simon, D. Sokolov and I.Zanevsky in 1896 (after: [Sokolov at al., 1897])

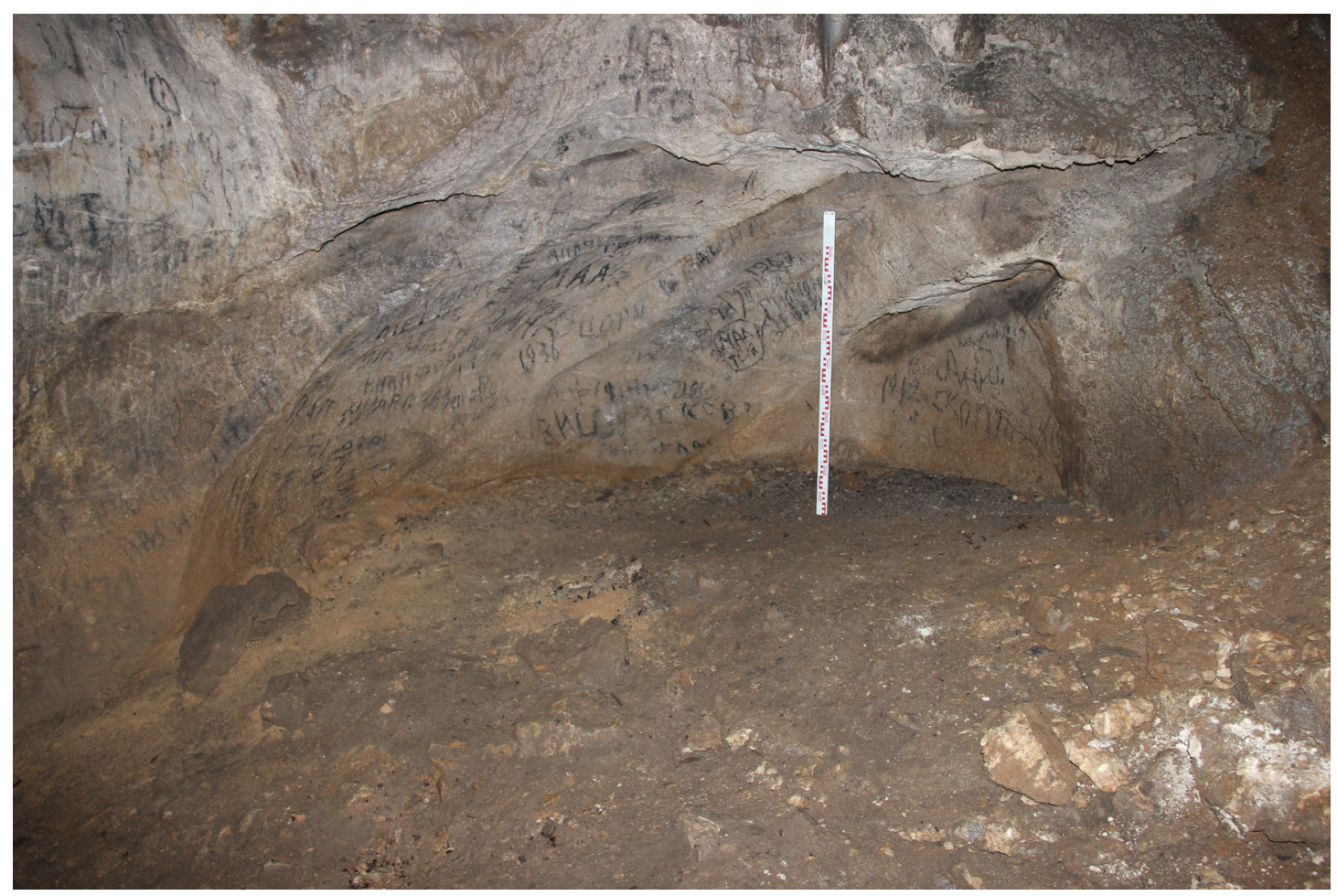

Рис. 4. Пещера Шульган-Таш (Каповая), зал Сталагмитовый. Вид на западную нишу с юго-востока. Фото В.Г. Котова, 2015 г.

Fig. 4. Shulgan-Tash (Kapova) cave, Stalagmite Hall. The view of the western recess from the southeast. Photo by V. Kotov, 2015 


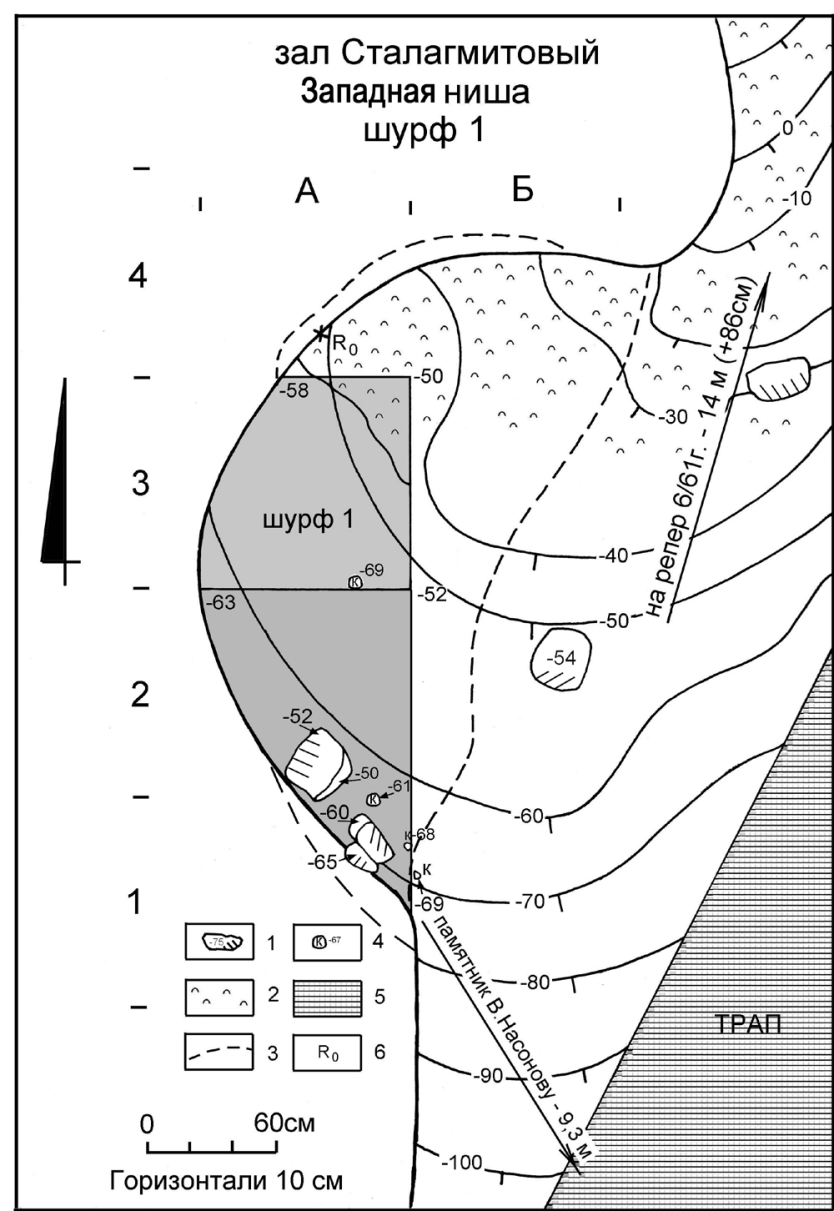

Рис. 5. Пещера Шульган-Таш (Каповая), зал Сталагмитовый. План ниши с шурфом 1 . Условные обозначения: 1 - камень; 2 - туфовые отложения; 3 - граница навеса/ниши; 4 - кости черепа человека; 5 - металлический трап; 6 - нулевой репер. Инструментальная съемка В.Г. Котова

Fig. 5. Shulgan-Tash (Kapova) cave, Stalagmite Hall. Plan of the recess and pit 1. Legend: 1 - rock; 2 - tuff sediments; 3 - border of the recess; 4 - human skull bones; 5 -metal ladder; 6 -zero check point. Surveying by V.Kotov

В последующем геолог Г.В.Вахрушев ошибочно полагал, что этот череп был найден между двух крайних глыб [Вахрушев, 1960. С.13; Житенев, 2011. C. 465-466].

Чepen № 2. В 2015 и 2017 гг. в Сталагмитовом зале Южно-Уральской палеолитической экспедицией ИИЯЛ УФИЦ РАН под руководством В.Г.Котова в небольшой нише западной стены, т.е. с противоположной стороны зала, примерно в $20 \mathrm{M}$ к юго-западу от места находки черепа № 1, был заложен шурф площадью $3 \mathrm{~m}^{2}$ [Котов, 2017; 2019]. В этой нише на поверхности пола были найдены фрагменты черепной крышки человека голоценовой сохранности (рис. 5). Затем в шурфе на глубине 15 см от поверхности в отложениях светло-бурой супеси, очевидно, позднего голоцена был расчищен фрагмент верхней челюсти человека, который находился там in situ (рис. 6, $A$ ). На этом же уровне в ходе расчистки были зафиксированы отдельные
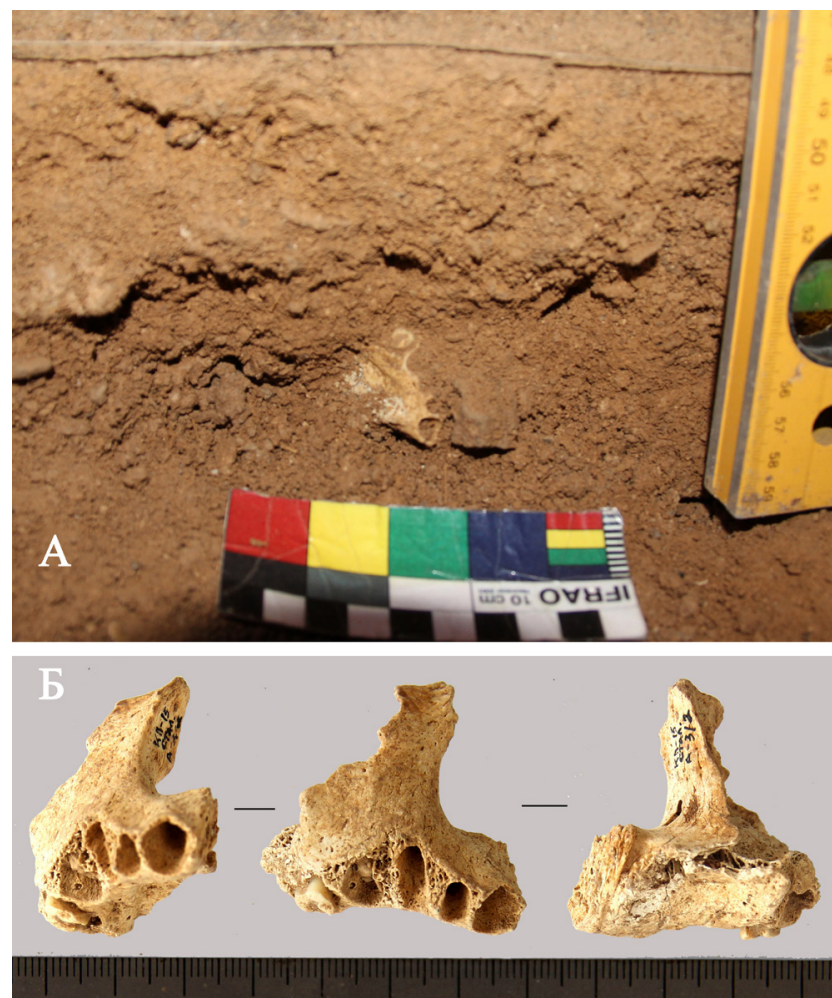

Рис. 6. Пещера Шульган-Таш (Каповая), зал Сталагмитовый. Ниша. Шурф 1. $A$ - фрагмент верхней челюсти человека в южной стенке шурфа (крупный план, вид с севера); 5 горизонт 2 , фрагмент верхней челюсти человека с зубами. Фото В.Г. Котова, 2018 г.

Fig. 6. Shulgan-Tash (Kapova) cave, Stalagmite Hall. Recess. Pit 1. $A$ - fragment of the human upper jaw in the southern wall (close-up, view from the north); $B$ - horizon 2, fragment of the human upper jaw with teeth. Photos by V. Kotov, 2018

угольки, кости мелких млекопитающих и птиц голоценовой сохранности [Котов, 2017. С.22]. В челюсти человека отсутствовали все зубы, которые, судя по фрагментам корней, были целенаправленно выбиты в древности (рис. 6, Б).

\section{Человеческие останки}

\section{в Купольном зале}

Зал Сталагмитовый отделен от следующего зала - Купольного - значительным понижением потолка. Переход между ними имеет высоту 1 м и ширину 9 м, отчего он и получил название «Ход Горло» (рис. 7). За этой перемычкой потолок постепенно повышается, образуя небольшую камеру, а в 8 м от входа потолок переходит в почти вертикальные стены зала Купольного. Ход Горло является своеобразным тепловым барьером между зоной переменного микроклимата, испытывающего внешние воздействия и зоной постоянных низких температур (около $+7^{\circ} \mathrm{C}$ ) с ограниченной циркуляцией атмосферы, характерных для внутренней части пещеры. На потолке это отмечено присутствием густой росы. ${ }^{2}$

Купольный зал получил свое название по характерному своду стен и потолка. Он имеет че-

\footnotetext{
${ }^{2}$ Отметим одну немаловажную деталь: в 2004 г. перед установкой решетки в начале хода Горло на границе со Сталагмитовым залом, строителями и сотрудниками заповедника была заложена траншея глубиной около 0,5 м, в которой была обнаружена кладка из крупных камней, идущая на всю ширину хода. Вместе с камнями были собраны несколько десятков костей животных, которые позже были переданы В.Г. Котову. К сожалению, археологическое наблюдение за вскрытием культурных отложений в этом месте не осуществлялось и данная конструкция детально не была зафиксирована.
} 


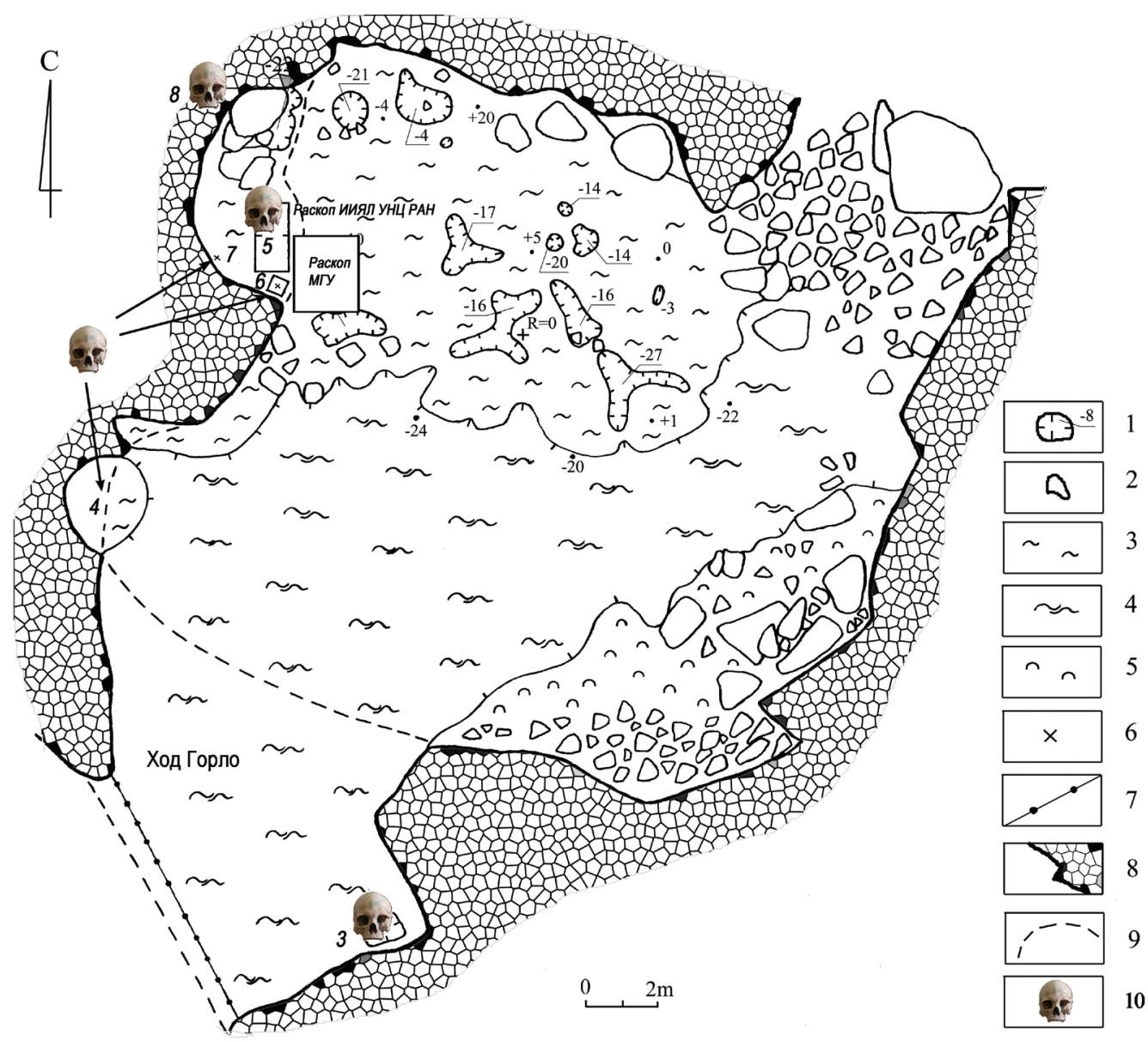

Рис. 7. Пещера Шульган-Таш (Каповая), зал Купольный. Условные обозначения: 1 - ямы; 2 - камни; 3 - рыхлые отложения; 4 - влажная глина; 5 - туфовые отложения; 6 - место находки черепов; 7 - решетка; 8 - стена; 9 - граница навеса. Инструментальная съемка В.Г. Котова, 2009 г.

Fig. 7. Shulgan-Tash (Kapova) cave, Dome hall. Legend: 1 - pits; 2 - rocks, 3 - soft sediments; 4 - wet clay; 5 - tuff sediments; 6 - skull finds; 7 - railing; 8 - wall; 9 - recess border. Surveying by V. Kotov, 2009

тырехугольные в плане очертания, ширина его составляет 18 м, длина 20 м, высота свода достигает 10 м (рис. 7). В зале имелось неглубокое озеро, образующееся после весеннего паводка и сильных дождей, которое называют «Летней речкой» [Cоколов и др., 1897]. Ежегодно во время таяния снега весь зал затапливается водой, поступающей из залов Знаков и Хаоса (рис. 3).

В разные годы в ходе Горло и в самом Купольном зале были обнаружены два черепа человека и несколько фрагментов черепов, а также кости посткраниального скелета человека.

Чepen № 3. Справа и в 6 м от решетки в небольшой камере хода Горло в 2009г. был обнаружен покрытый кальцитовым натеком череп человека, выступавший над современной поверхностью пола на $6 \mathrm{~cm}$. На месте его находки в этом же году экспедицией МГУ был заложен шурф размером $1 \times 1$ м, показавший наличие небольших древесных угольков и полное отсутствие каких-либо других находок [Житенев, 2011. С.463-464]. Череп залегал в голоценовых отложениях и принадлежал молодой женщине (рис. 8). По наблюдениям В.Г. Котова, осмотревшего шурф в процессе раскопок, череп залегал в сероватом суглинке, в котором встречались крупные и средние известняковые камни и присутствовали туфовые образования (рис. $8, A$ ). По этим признакам условия залегания идентичны черепу № 5 в раскопе 1 в Купольном зале. С разрешения В.С. Житенева череп был сфотографирован В.Г. Котовым (рис. 8, Б). Антрополог Р.М. Юсупов (ИИЯЛ УФИЦ РАН) по фотографии предварительно определил, что череп принадлежал молодой женщине и по характерным признакам он сходен с черепом № 5 [Юсупов, Нечвалода, 2010. C. 108; Пещерное..., 2019. С.38]. У этого черепа видно, что левая скуловая кость обломана и на левой поверхности присутствует длинная трещина (рис. 8,Б). По устному замечанию Р.М. Юсупова, данный череп принадлежал представителю уральского расового типа.

Череn № 4. Очередная находка человеческих останков в Купольном зале была сделана в 1995 г. Р.Ф.Муллагуловым, учителем географии средней школы № 1 города Сибай. Вместе со своими учениками он, во время экскурсии по среднему этажу пещеры Шульган-Таш, в Низком переходе зала Купольного в одной из ниш западной стены обнаружил 6 костей, среди которых нижняя челюсть, теменная крышка, фрагмент левой верхней челюсти человека и три кости скелета (рис.7). Впоследствии они были переданы в Сибайский краеведческий музей. К настоящему времени сохранились только две кости человека - фрагменты черепной крышки и верхней челюсти, которые были переданы для изучения в ИИЯЛ УФИЦ РАН (рис. 9). 

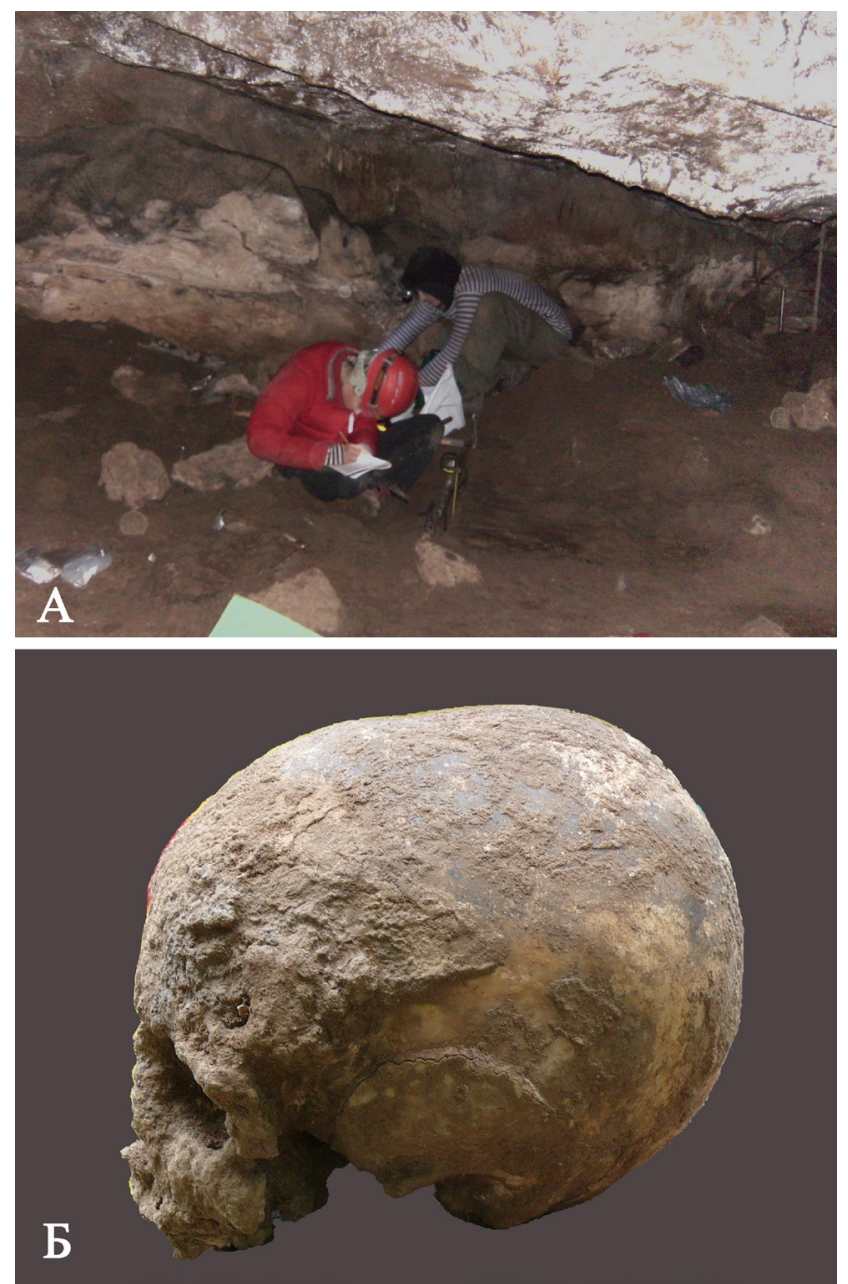

Рис. 8. Пещера Шульган-Таш (Каповая), низкий Переход зала Купольного. $A$ - вид на шурф 2 с запада; $D$ - череп № 3 из шурфа 2. Фото В.Г.Котова, 2009г.

Fig. 8. Shulgan-Tash (Kapova) cave, Low passage of the Dome hall. $A$ - view of the pit 2 from the west; $B$ - skull №3 from the pit2. Photos by V. Kotov, 2009

По определению А.И.Нечвалоды, находки принадлежали одному индивиду, возраст которого 6-7лет, пол не определен. Также кости были изучены В.Г. Котовым с помощью микроскопа МБС10. Фрагмент верхней левой челюсти человека имеет размер $7,0 \times 6,1 \times 2,1 \mathrm{~cm}$ (рис. $9, A$ ). На нижней поверхности у основания скулового отростка обнаружены следы срезания свежей кости протяженностью около 1 см, сделанные, судя по следам, металлическим ножом (рис. $9, A, 3)$. На скуловом отростке ближе к его концу фиксируются глубокие борозды, идущие в продольном направлении, являющиеся следами скобления (рис. 9, $A, 2$ ). Также на вогнутой поверхности расположены нарезки и параллельные царапины - следы соскабливания мягких тканей с поверхности кости (рис. $9, A, 1)$. Вблизи альвеол на внутренней поверхности неба присутствуют участки заглаженности и яркой заполировки на выступающих участках, возникшие от продолжительного трения кости о мягкие кожаные поверхности.

Размеры затылочной кости: от точки лямбда до точки на крае перелома $-8,8$ см, наибольшая ширина $-9,9$ см (рис. $9,5,1)$. Ее основание в ме- сте перегиба было фрагментировано сколами, образующими вдоль осевой линии выступ и две симметричные выемки. Это подтверждается и А.И.Нечвалодой: «Затылочная кость лишена базилярной части (pars basilaris), судя по всему, в результате намеренного воздействия на кость. В области нижней выйной линии, в области перехода чешуи затылочной кости к телу, хорошо различимы следы обработки перелома поверхности кости». ${ }^{3}$ Ровно посередине на выступе проходит рубец длиной 12 мм, шириной в основании 0,8 мм и глубиной 0,5 мм (рис. $9,5,4)$. Левая его сторона слегка скошенная, правая более крутая. Очевидно, удар был нанесен каким-то крупным ножом или кинжалом по основанию черепа, когда череп был уже отделен от шеи и очищен от мягких тканей. На внешней выпуклой поверхности имеются параллельные нарезки длиной 1-2cм, идущие с разным интервалом перпендикулярно продольной оси, оставленные острым режущим металлическим инструментом (рис. 9, $5,3,6$ ). Возможно, это следы снятия с головы кожи или скальпа. Кроме того, всю поверхность покрывают множество разнонаправленных царапин, возникших от продолжительного использования, во время которого выпуклая сторона кости многократно соприкасалась и терлась о крупнозернистые поверхности (рис. 9, $5,2)$. Между тем, края кости по всей длине имеют характерное закругление кромки, заглаженность и яркую заполировку. Перпендикулярно краю с внешней и внутренней сторон присутствуют многочисленные борозды и царапины, появившиеся в ходе операций, в которых внешняя поверхность кости скользила и терлась о зернистую поверхность, причем выступающие острые края кромки не были обломаны. Возможно, что данные следы могли возникнуть в процессе использования этой кости в качестве ложки-черпака или емкости для пищи (рис. 9, Б, 5, 6, 8). Об этом свидетельствуют и глубокие царапины и борозды разной направленности, имеющиеся внутри вогнутых поверхностей черепной крышки, появившиеся, скорее всего, в результате разрезания металлическим ножом каких-то мягковолокнистых материалов, помещаемых внутрь вогнутой поверхности кости (резание кусков пищи?).

Таким образом, череп человека после очищения от мягких тканей вместе с нижней челюстью и другими костями скелета был помещен в нишу Низкого перехода и использовался в каких-то ритуальных (?) действиях. А затем, после фрагментации черепа по швам, и, возможно, через много лет после первоначального помещения в пещеру, затылочная кость употреблялась в качестве сосуда или черпака [Пещерное..., 2019. С. 168-170].

Чepen №5. Первая антропологическая находка в Купольном зале была описана еще в XVIII в. известным историком, членом-корреспондентом Императорской академии наук П.И. Рычковым, который увидел в 1760 г. в небольшой «кругловатой

${ }^{3}$ Благодарим антрополога А.И. Нечвалоду (ИИЯЛ УФИЦ РАН) за анализ костей из Сибайского музея и их описание. 

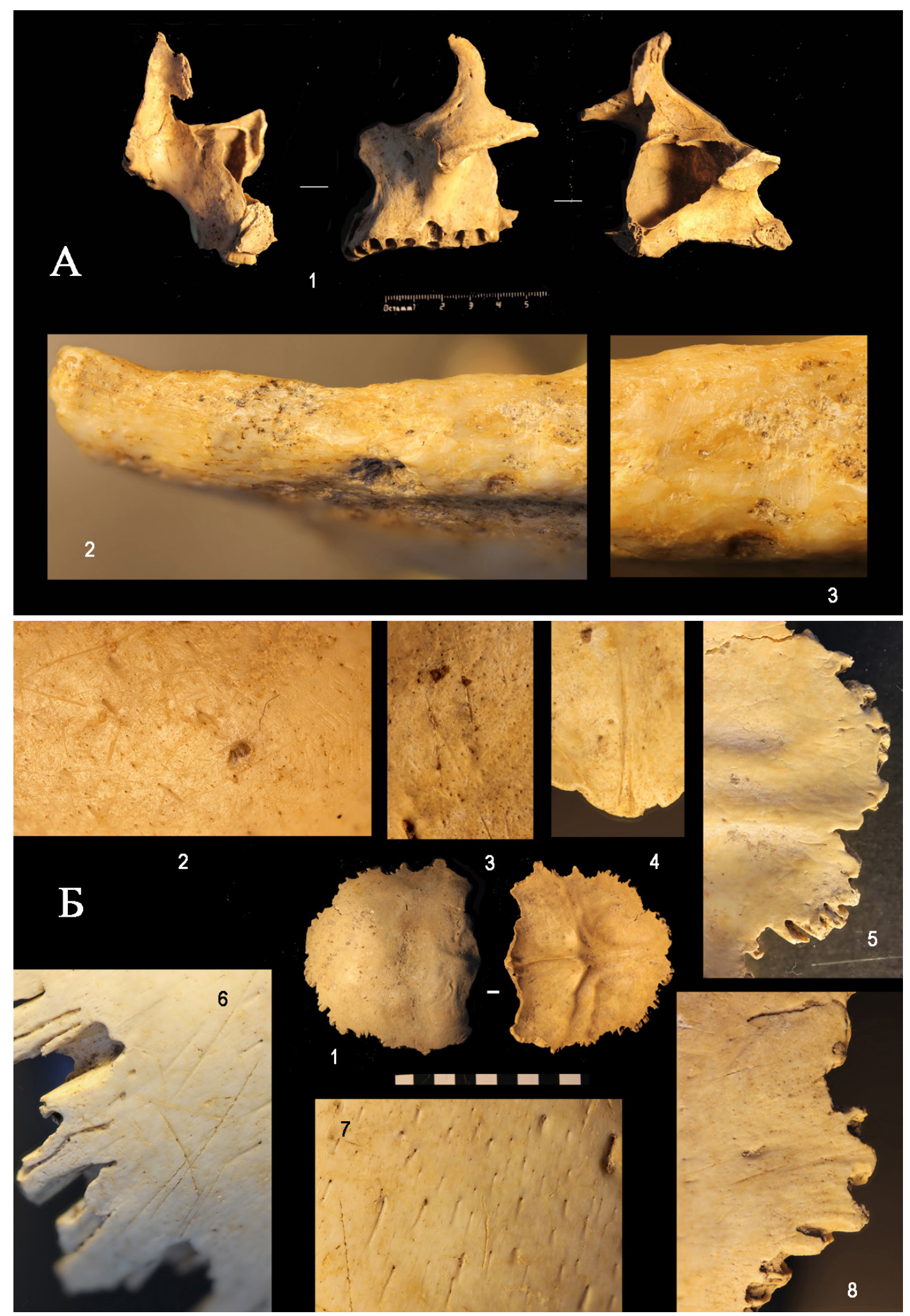

Рис.9. Пещера Шульган-Таш (Каповая), зал Купольный. $A$ - фрагмент верхней челюсти человека. $1-$ фото кости в трех ракурсах; 2 - нижняя поверхность скулового отростка (увеличение $\left.10^{x}\right) ; 3$ - участок со следами срезания, крупный план $\left(15^{x}\right)$. 5 - фрагмент черепной крышки человека. 1 - фото кости в двух ракурсах; 2 - следы повреждений в центральной части кости $\left(10^{x}\right) ; 3$ - нарезки в правой части кости $\left(10^{x}\right) ; 4-$ рубец в основании кости $\left(10^{x}\right) ; 5$ - следы использования на внутренней поверхности кости $\left(10^{x}\right) ; 6$ - нарезки и следы использования на левом участке внешней поверхности кости $\left(10^{x}\right) ; 7-$ борозды и углубления в скоплении на левом участке внешней поверхности $\left(15^{\times}\right) ; 8$ - следы использования на правом верхнем участке внешней поверхности $\left(10^{\mathrm{x}}\right)$. Фото В.Г. Котова и М.М. Румянцева, 2019 г.

Fig. 9. Shulgan-Tash (Kapova) cave, Dome hall. $A$ - fragment of the the human upper jaw. 1 - photo of the bone from three angles; 2 - the lower surface of the zygomatic process (enlargement $\left.10^{\mathrm{x}}\right) ; 3$ - fragment with cutting traces, close-up $\left(15^{\mathrm{x}}\right)$. $B$ - fragment of the human skull roof. 1 - photo of the bone from two angles; 2 - traces of damaging in the central part of the bone $\left(10^{\mathrm{x}}\right) ; 3$ - cuts in the right side of the bone $\left(10^{x}\right) ; 4$ - scar at the base of the bone $\left(10^{x}\right) ; 5$ - use-wear traces at the inner surface of the bone $\left(10^{x}\right) ; 6$ - cuts and usewear traces of use on the left side of the outer surface of the bone $\left(10^{\mathrm{x}}\right) ; 7$ - grooves and dents in the accumulation on the left side of the outer surface $\left(15^{\mathrm{x}}\right) ; 8$ - use-wear traces at the upper right part of the outer surface $\left(10^{\mathrm{x}}\right)$. Photos by V.Kotov and M. Rumyantsev, 2019 


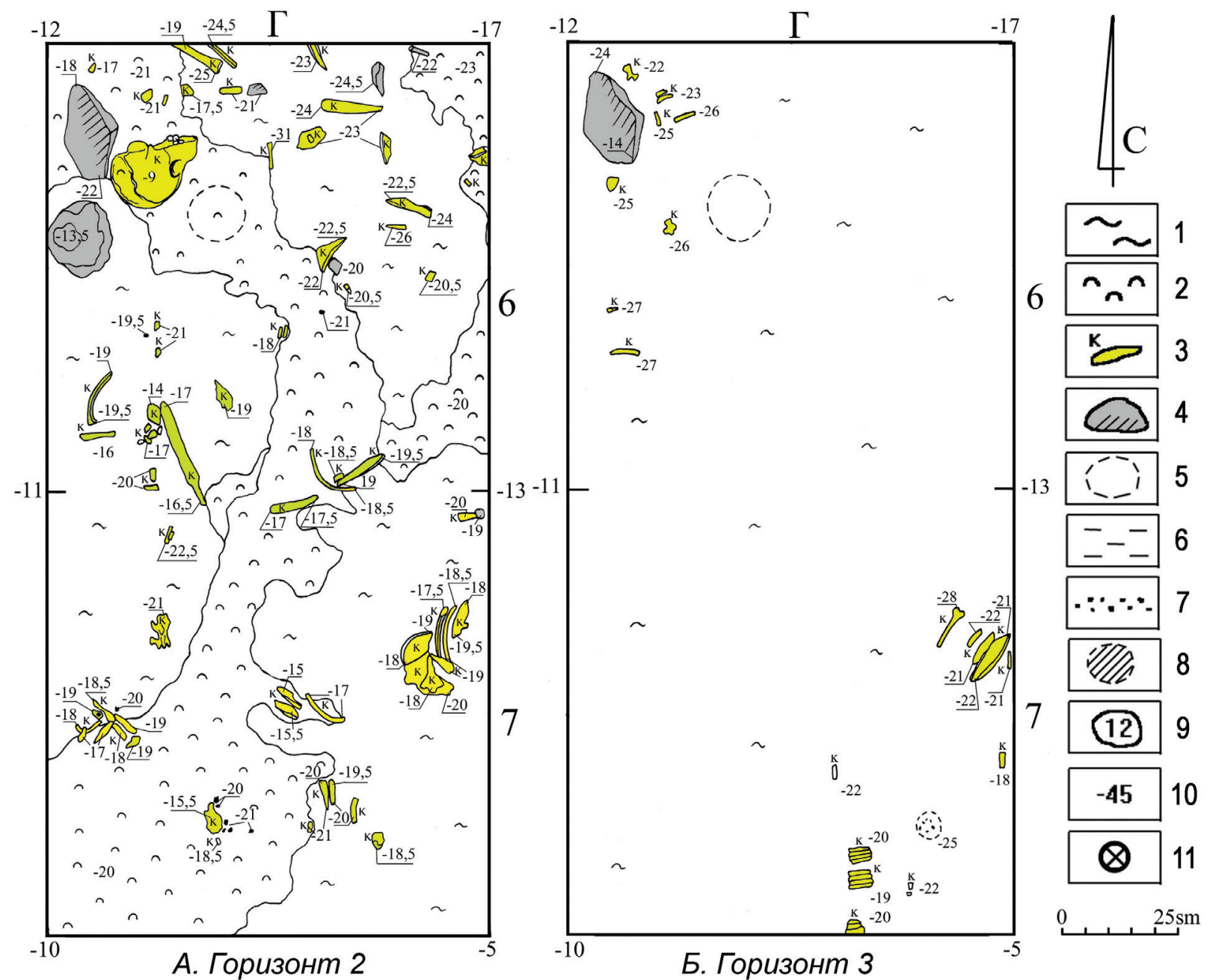

Рис. 10. Пещера Шульган-Таш (Каповая). Зал Купольный, раскоп 1. План горизонтов 2 (A) и 3 (Б). Условные обозначения: 1 - рыхлые отложения; 2 - туфовые отложения; 3 - кость; 4 - камень; 5 - место сбора СП-образцов; 6 - сероватый суглинок; 7 - угольки; 8 - скопление охры; 9 - номер находки; 10 - глубина; 11 - отщеп

Fig. 10. Shulgan-Tash (Kapova) cave. Dome hall, excavation 1. Plan of horizons 2 (A) and 3 (B). Legend: 1 - soft sediments; 2 - tuff sediments; 3 - bone; 4 - rock; 5 - collection point of spore and pollen samples; 6 - grey loam; 7 - charcoals; 8 -ochre; 9 -find number; 10 - depth; 11 - flake

пещере» слева, сразу за низким переходом «сухую человеческую голову» - череп человека [Рычков, 2007. С.20]. Судя по описанию этого места, череп человека он увидел в нише в западной стене Купольного зала, в 150 м от входа в пещеру (рис. 7). Ниша арочной формы, размеры по границе навеса западной стены: высота 1,5 м, длина 7 м, глубина $4 \mathrm{M}$.

В 2009г. в этой же нише В.Г.Котовым были обнаружены два фрагмента черепных крышек и раскопом вскрыто место находки целого черепа человека (№ 5) [Котов, 2010а. С. 56]. После этих находок ниша получила название «Капелла Черепов» [Котов, 2010а. С.52]. В.Г.Котов полагает, что «сухая человеческая голова», которую видел П.И. Рычков, и череп № 5 из Капеллы Черепов - это один и тот же череп. Внутри этой ниши и рядом в 2009 и 2010 гг. были заложены два раскопа (первый - экспедиция ИИЯЛ УФИЦ РАН, рук. В.Г. Котов, второй - экспедиция МГУ, рук. В.С. Житенев), которые показали, что в данном месте сохранился участок с многочисленными культурными слоями эпохи голоцена и плейстоцена [Котов, $2010 б$.
С. 76-77; Житенев, 2012; 2014; Пещерное..., 2019. C. 118-138].

Череп №5 был исследован раскопом 1 , вписанным в ориентированную по сторонам света метровую сетку квадратов. С севера на юг она имеет цифровое, а с запада на восток - буквенное обозначения. Размеры раскопа $2 \times 1$ м, охватывает квадраты Г-6 и Г-7. В 2010 г. к этой же сетке был привязан раскоп В.С.Житенева (квадраты Д/Е-7/8, а также Г-8). Раскоп 1 расположен в 2 м к востоку от западной стенки Капеллы Черепов, высота потолка ниши в этом месте составляет 1,5 м. Отложения разбирались зачистками с помощью ножей и полностью промывались на мелком сите вне пещеры. Фиксация находок и камней производилась условными горизонтами мощностью 5 см. Раскоп был доведен до глубины 0,75 м от поверхности и с 6 условного горизонта (глубина $0,25-0,3$ м от поверхности) были зафиксированы плейстоценовые отложения светло-бурого суглинка [Пещерное..., 2019. С. 118].

В ходе расчистки горизонта 1 раскопа 1 в отложениях сероватого суглинка были зафиксированы 

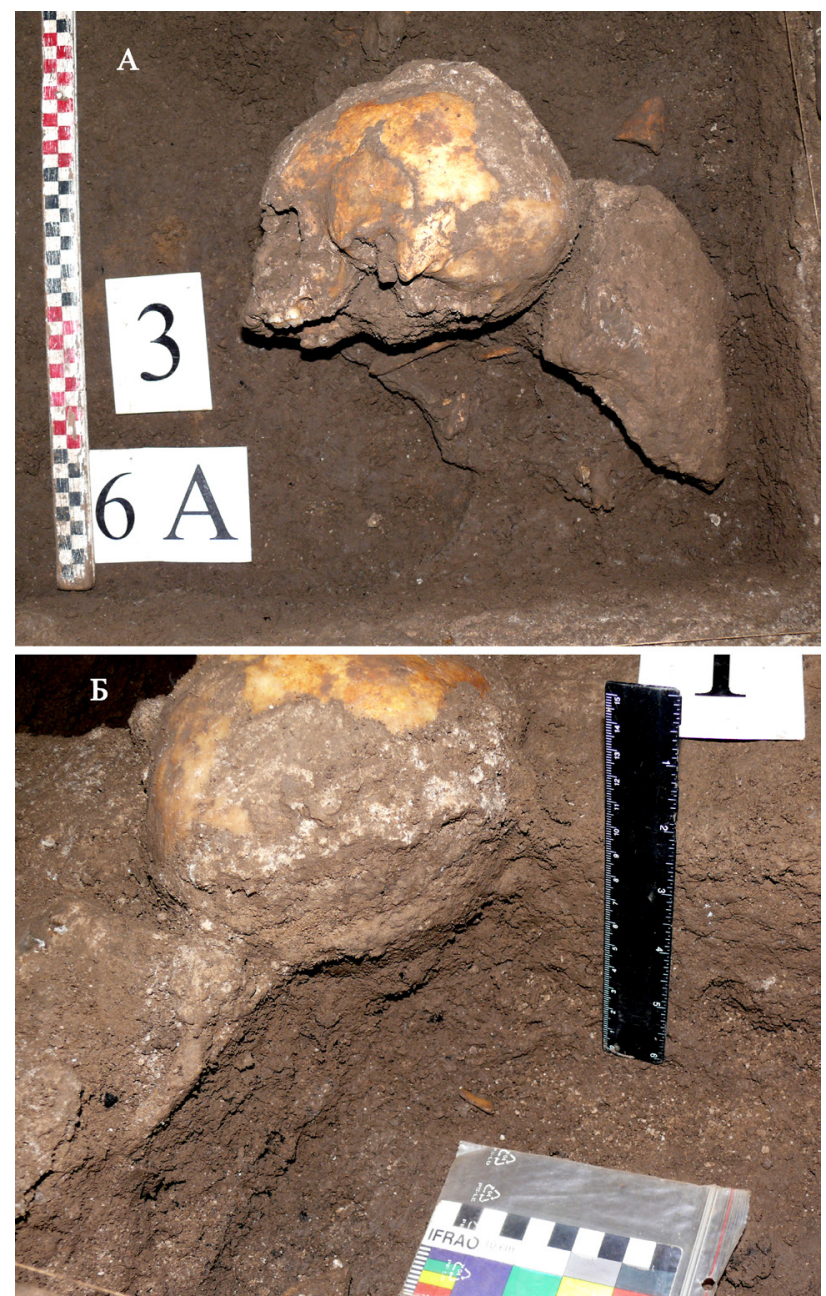

Рис. 11. Пещера Шульган-Таш (Каповая). Зал Купольный, раскоп 1. $A$ - вид на череп на уровне горизонта 3 с севера; $D$ - вид на череп на уровне горизонта 3 с юга. Фото В.Г. Котова, 2009 г.

Fig. 11. Shulgan-Tash (Kapova) cave. Dome hall, excavation 1. $A$ - view of the skull at the level of horizon 3 from the north; $B$ - view of the skull the level of horizon 3 from the south. Photos by V. Kotov, 2009

отдельные угольки и фрагмент кости, а в основании слоя присутствовали туфовые образования [Котов, 2010б. С.15]. Череп человека залегал in situ на глубине 10 см от поверхности, на уровне основания 2 условного горизонта, и был заключен в три слоя натечных образований внутри сероватого суглинка (рис. 10; 11). Кальцитовые отложения толщиной 1-2см были зафиксированы в основании 2 условного горизонта. Последнее однозначно свидетельствует о непотревоженности отложений. С другой стороны, это позволяет разделить отложения в раскопе 1 на очень условные «культурные слои», соответствующие горизонтам вскрытия раскопа. Следует отметить важную деталь: в основании 2 условного горизонта зафиксирован слой кальцитового натека, который отделяет слой с черепом человека и скоплением костей животных от нижележащего 3 слоя (рис. $10, A$ ). Отложения 3 условного горизонта представлены сероватым суглинком с включениями туфовых образований, а в основании горизонта в кв. Г-6 присутствует прослойка светло-бурого суглинка, которая указывает на возможность объединения этого условного горизонта в самостоятельный культурный слой.
Среди костей животных здесь были зафиксированы угольки и два коренных зуба молодого человека [Котов, 2010б. С. 16].

На поверхности пола перед раскопками была видна только незначительная часть свода черепа человека, сама же черепная коробка лежала на правом боку, лицевой стороной на юг, в слое сероватого легкого суглинка с фрагментами костей животных и углями (рис. 10; 11). По уголькам из подстилающего условного горизонта 3 были получены две калиброванных ${ }^{14} \mathrm{C}$ даты - 3020 \pm 30 , доверительный интервал 3081-3341 BP (Poz-107851)

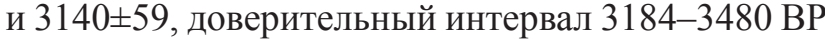
(NSKA-01923) [Пещерное..., 2019. С. 78, 347]. Таким образом, эти даты показывают хронологический интервал XIV-XIвв. дон.э.

По мнению Р.М.Юсупова и А.И.Нечвалоды, череп № 5 принадлежал девушке 16-17 лет. При осмотре черепа было обнаружено отсутствие левой скуловой кости. От левого края лобной кости до уровня середины лба между лобными буграми идет сквозная косая трещина, ее длина около 60 мм, следы заживления отсутствуют (рис. 12, $A$ ). Повреждение было нанесено сильным ударом каким-то тупым твердым предметом, от которого, очевидно, и наступила смерть. Антропологический тип умершей отнесен к одному из вариантов местной уральской расы, широко распространенному среди женской половины башкир горно-лесных и восточных районов Южного Урала [Юсупов, Нечвалода, 2010. С. 109]. По черепу А.И.Нечвалодой была сделана пластическая реконструкция лица по черепу (рис. 12, Б).

Вместе с черепом, начиная с 1 и до 4 условного горизонта (т.е. до глубины 0,2 м) были найдены 67 костей животных, причем основное скопление костей было приурочено ко 2 (глубина 5-10 см) и 3 условным горизонтам (глубина 10-15 см) [Котов, 2010б. С. 15]. Фаунистический материал был описан и проанализирован Д.О.Гимрановым (ИЭРиЖ УрО РАН, Екатеринбург) [Гимранов, 2011. С.71]. Животные представлены следующими видами: бурый медведь - 1 кость черепа (гор.2), свинья (дикая или домашняя) - 1 кость черепа (гор.2), лошадь - 2 фрагмента нижней челюсти (гор.2) и 1 фрагмент нижней челюсти (гор.3), по 4 фрагмента ребер мелкого рогатого скота были найдены на горизонтах 3 и 4; остальные фрагменты костей неопределимы. На некоторых костях крупного, мелкого рогатого скота и лошади фиксируются нарезки, а также следы рубки. Необходимо отметить, что ряд животных представлен фрагментами черепов (бурый медведь, лошадь, свинья/кабан). Кости животных из условных горизонтов 1-4 и кости животных с поверхности пола Капеллы Черепов имеют одинаковый позднеголоценовый тип сохранности, сходный с сохранностью человеческого черепа из раскопа 1. Основным фактором накопления костей животных на этом участке являлась человеческая деятельность [Гимранов, 2011. С. 72].

На условном горизонте 3 раскопа 1 обнаружены два резца человека и левая ветвь нижней челю- 


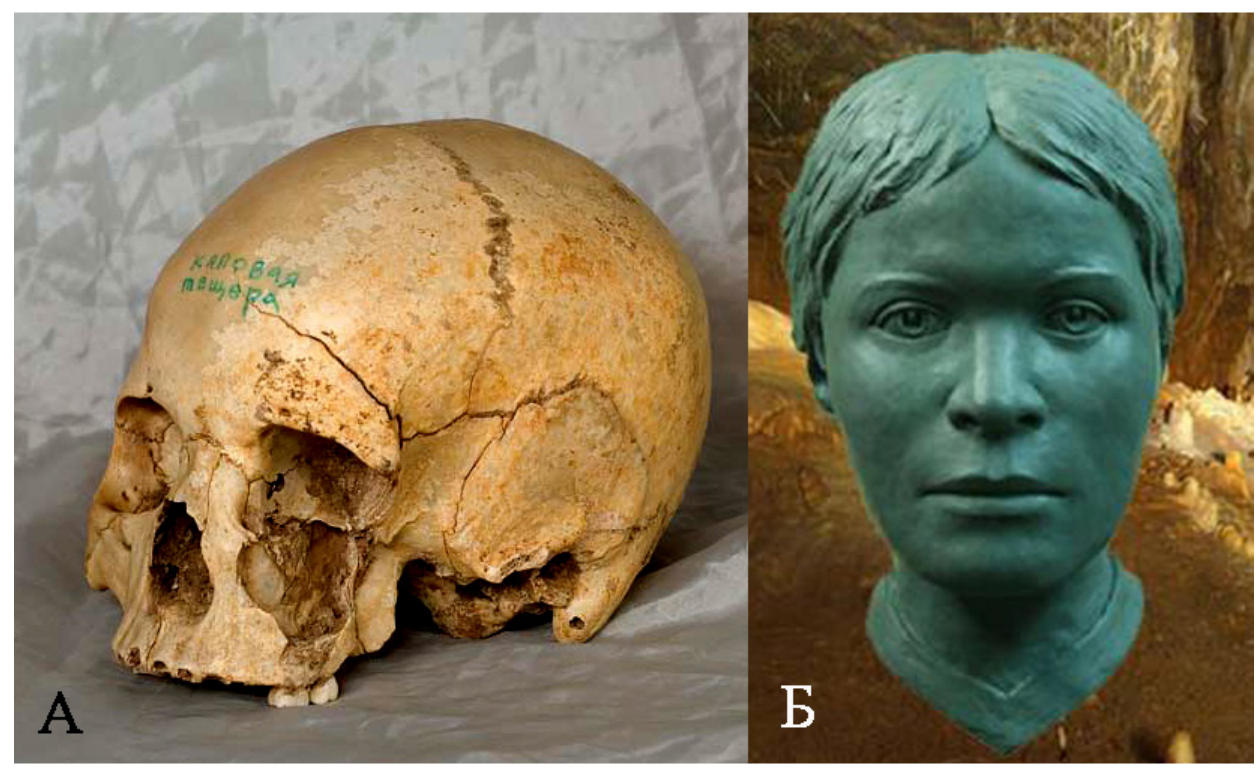

Рис. 12. Пещера Шульган-Таш (Каповая). Зал Купольный, раскоп 1. $A$ - череп человека № 5; $Б$ - пластическая реконструкция лица по черепу № 5

Fig. 12. Shulgan-Tash (Kapova) cave. Dome hall, excavation 1. $A$ - human skull № 5; $B$ - forentic facial reconstruction by the skull № 5

сти подростка (возраст - около 12 лет, определение Р.М. Юсупова) [Котов, 2010б. С. 15]. Внутри этих отложений были обнаружены отдельные угольки, не образующие скоплений (рис. 10,Б). По наблюдениям автора раскопок, данные отложения испытали воздействие воды, скорее всего, периодических подтоплений во время весенних паводков. Это приводило к перемещению углей и мелких костей под своды нависающих стен, а также к образованию застойных водоемов внутри понижений пола Капеллы Черепов [Котов, 2010б. С. 16].

Yepen № 6. Был обнаружен в сентябре 2008 г. В.Г.Котовым во время осмотра и измерения западной ниши (Капеллы Черепов). Фрагмент свода черепа лежал на поверхности пола в 0,5 м от нависающего потолка ниши, в 2 м к югу от черепа №5. Видимый размер находки составлял $8 \times 8 \mathrm{~cm}$ (рис. 13). Кость была оставлена на месте in situ для выяснения ее связи с культурными отложениями на следующий год здесь предполагалось заложить шурф. В 2009 г. место находки было вскрыто небольшим шурфом экспедицией МГУ, впоследствии превращенным в раскоп [Житенев, 2012. Рис. 8; 2014. Рис. 2].

Размеры раскопа экспедиции МГУ $-2 \times 2 \mathrm{M}$, вместе с шурфом, примыкающим к раскопу с юго-

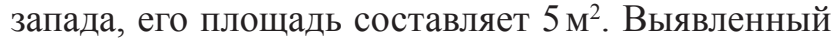
в шурфе фрагмент черепа представлял собой черепную крышку, немного выступавшую над современной поверхностью и отделенную от основного культурного слоя стерильной прослойкой [Житенев, 2012. С. 156]. Культурный слой залегает на глубине 0,18-0,32 м и сверху частично перекрыт кальцитовым натеком, выше которого и залегает слой стерильного суглинка. Важно уточнение автора исследований о том, что верхняя часть культурного слоя была перекрыта кальцитовым натеком, а все находки были «впаяны» в его подошву [Житенев, 2014. С. 118]. Судя по стратиграфическим разрезам, культурный слой резко выклинивается в южном и западном направлениях, а его основное пятно представляет собой «подовальное скопление золисто-углистой массы» с большим количеством находок, которое исследовано менее чем наполовину [Житенев, 2012. С. 158. Рис. 4-7]. Находки в раскопе, помимо многочисленных костей животных, ${ }^{4}$ представлены рыбьей чешуей, зубом человека, раковиной и четырьмя фрагментами керамики, относящимися к межовской культуре. Судя по опубликованным фото, находки керамики связаны с самой верхней частью культурного слоя [Житенев, 2012. Рис. 7; 9]. Сам зафиксированный культурный слой неоднороден, так как в ряде мест прослежено его разделение на две части углистой прослойкой [Житенев, 2012. Рис. 4; 5], а выше перекрывающего стерильного слоя расположена еще одна углистая прослойка - горизонт посещений, связываемый автором исследований «уже с деятельностью представителей других культурноисторических обществ» [Житенев, 2012. С. 156].

Описываемый раскоп расположен юго-восточнее раскопа ИИЯЛ УФИЦ РАН, в котором был исследован череп №5. Площадь обоих раскопов составляет $7 \mathrm{~m}^{2}$, при этом раскоп ИИЯЛ УФИЦ

\footnotetext{
${ }^{4}$ К сожалению, ни в одной из статей В.С. Житенева не представлено количественных данных и определения найденных в раскопе костей. Исключением является фраза, характеризующая основное пятно культурного слоя: «...с большим количеством фаунистического материала и костных останков человека» [Житенев, 2012. С. 158]. На этом фоне важно, что все кости из раскопа ИИЯЛ УФИЦ РАН, расположенного непосредственно к западу - северо-западу от раскопа МГУ, атрибутированы и описаны (см. выше). Из 70 найденных костей только 3 относятся к человеческим (два зуба и фрагмент нижней челюсти), а все остальные - к диким и домашним животным, при этом кости домашних животных имеют вид «кухонных остатков». Эти выводы позволяют допускать наличие в раскопе МГУ только незначительного количества костей человека, либо их полное отсутствие (за исключением найденного в квадрате Д-8 зуба).
} 


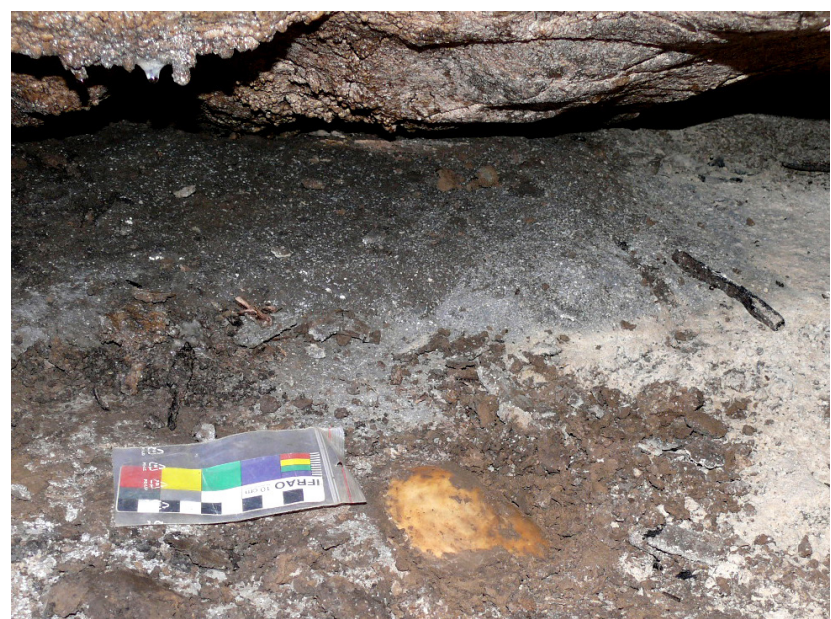

Рис. 13. Пещера Шульган-Таш (Каповая). Зал Купольный, раскоп 1. Вид на фрагмент черепной крышки человека № 6 in situ. Фото В.Г. Котова, 2008 г.

Fig. 13. Shulgan-Tash (Kapova) cave. Dome hall, excavation 1. View of the human skull roof fragment № 6 in situ . Photo by V.Kotov, 2008

РАН характеризует специфику отложений северо-западной части площадки (в глубине Капеллы Черепов), а раскоп МГУ - южную и восточную части. Важно отметить, что восточный край раскопа МГУ приурочен к самому краю низкой ниши Капеллы Черепов, находясь уже в общем пространстве Купольного зала. Из этого следует, что имеющее четкие границы пятно культурного слоя («подовальное скопление золисто-углистой массы») приурочено к границе Капеллы Черепов и основной части Купольного зала, фактически на линии входа в Капеллу.

Важно, что описанный культурный слой, перекрытый кальцитовым натеком, соответствует по глубине культурному слою 3 (условный горизонт3) раскопа 1, который также перекрыт кальцитовым натеком. Прослойку угля, залегавшую выше и отделенную стерильными отложениями от этого культурного слоя, можно сопоставить с культурным слоем 2 в раскопе 1 . Находки костей и угольков вместе с находками костей человека и животных на поверхности пола Капеллы Черепов следуют относить к верхнему культурному слою.

Чepen № 7. В 1,5 м к северу от черепа № 5 под сводами Капеллы Черепов обнаружено два десятка фрагментов костей домашних животных такой же сохранности. Здесь же был обнаружен фрагмент теменной кости черепа человека (№ 7) размером $2 \times 4$ см, на поверхности которого зафиксированы следы 10 крупных рубцов, нанесенных крупным и относительно тяжелым металлическим острым режущим инструментом под прямым углом к поверхности головы, а также скользящих рубящих ударов, нанесенных под острым углом (рис. 14). Возможно, что в результате этих ударов свод черепа молодого человека (определение Р.М.Юсупова) и был фрагментирован на небольшие куски. Необходимо отметить, что фрагментация человеческого черепа могла произойти гораздо позже его

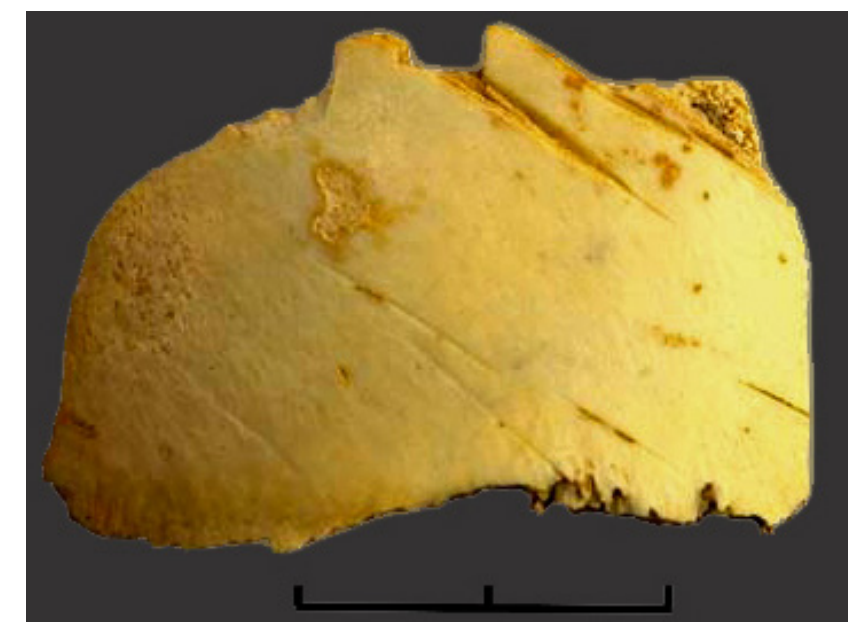

Рис. 14. Пещера Шульган-Таш (Каповая). Зал Купольный, раскоп 1. Фрагмент черепной крышки человека № 7. Макросъемка В.Г. Котова, 2009 г.

Fig. 14. Shulgan-Tash (Kapova) cave. Dome hall, excavation1. View of the human skull roof fragment № 7 . Macro photo by V.Kotov, 2009

помещения в пещеру, но еще в древности. Об этом свидетельствует одинаковая сохранность поверхности кости и рубцов на ней. Кроме того, фрагментация черепов зафиксирована и в других случаях на данном памятнике, в том числе, и среди находок в культурном слое. Сохранность и цвет кости этого фрагмента сходны с черепом № 5 из раскопа 1 и с другими находками костей из основного голоценового культурного слоя. Особенности следов указывают на характер инструмента, с помощью которого была произведена фрагментация черепа - это, скорее всего, был металлический кинжал.

Скопление костей человека, черепа № 8 и №9. В 2020 году в ходе поиска гравированных изображений в расщелине стены Капеллы Черепов были замечены какие-то кости [Котов, 2021]. Они лежали на дне небольшой полости, соединенной с Капеллой Черепов узкой трещиной, начинающейся круглым отверстием диаметром 15 см на высоте от пола около 1,2 м (рис. $7 ; 15)$. Одному из участников экспедиции удалось подлезть под свод Капеллы Черепов и достать через боковую трещину кости, лежавшие на поверхности полости. Всего из расщелины удалось достать 34 кости. Из них 23 кости принадлежали животным (крупным млекопитающим), остальные 11 костей определены как человеческие. ${ }^{5} \mathrm{~B}$ том числе, четыре кости являлись фрагментами черепа годовалого ребенка (далее череп № 8) (рис.16, 1, 2,4), а крупный фрагмент лицевой части черепа (череп №9) принадлежал взрослому человеку (рис. 16,3). Остальные кости принадлежали посткраниальному скелету взрослого человека: две лопатки, позвонок, кость грудины, 3 фрагмента ребер (рис. 16, 5-11). Сохранность костей позднеголоценовая: кости плотные, светло-желтого окраса, легкие, некоторые были частично покрыты тонкими кальцитовыми корками.

\footnotetext{
${ }^{5}$ Определения костей человека - антрополог А.И.Нечвалода, костей животных - археозоолог А.А. Романов (ИИЯЛ УФИЦ РАН).
} 


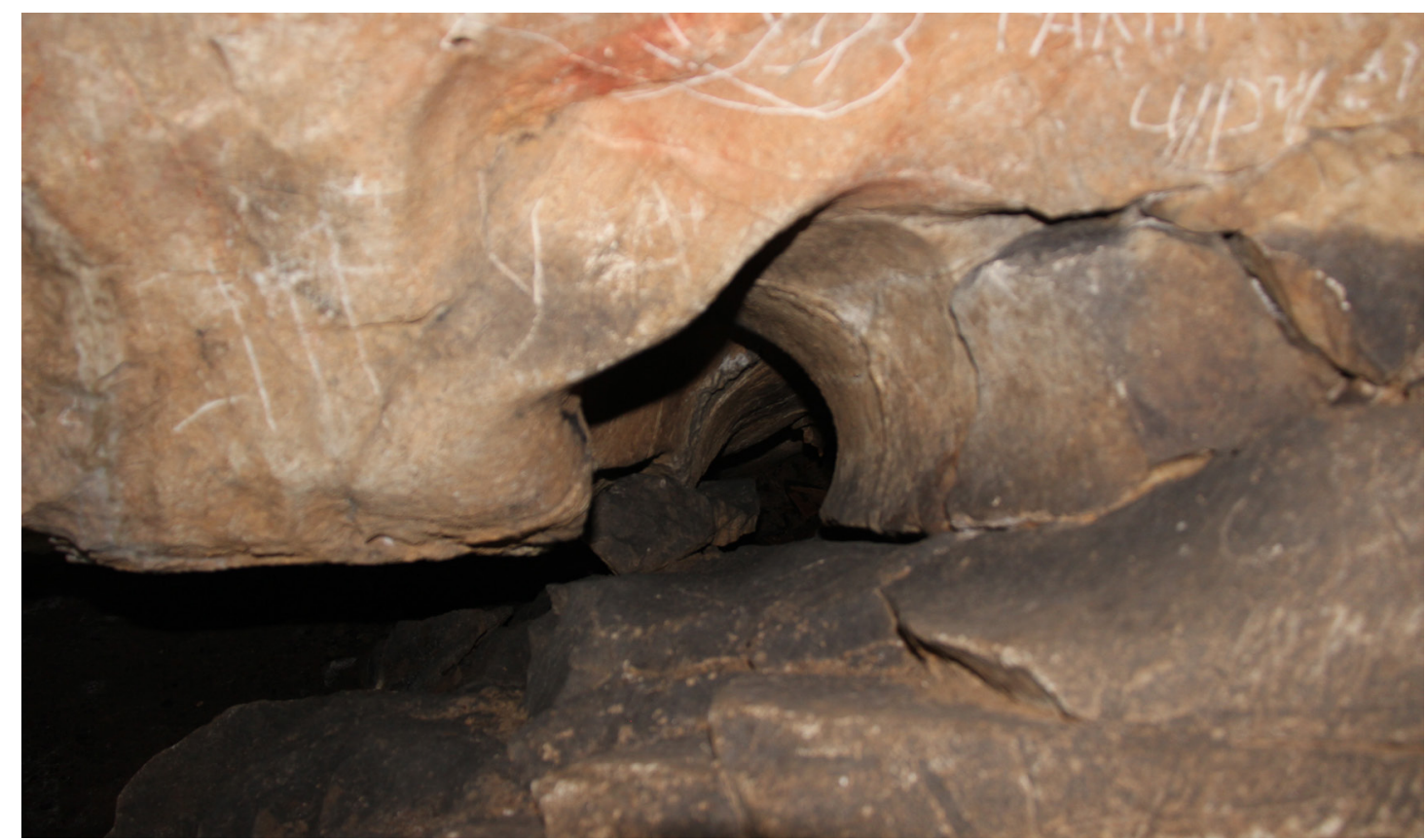

Рис. 15. Пещера Шульган-Таш (Каповая). Зал Купольный, Капелла Черепов. Расщелина в стене. Вид с востока. Фото В.Г. Котова, 2020 г.

Fig. 15. Shulgan-Tash (Kapova) cave. Dome hall, Skull Chapel. Cleft in the wall. View from the east. Photo by V. Kotov, 2020

Теоретически эти кости могли попасть в полость через трещину во время сильного паводка, когда поверхность пола Купольного зала не только покрывалась водой, но и представляла собой бурный поток, что в принципе маловероятно. Не исключено, что некоторые кости могли быть затащены в трещину каким-либо достаточно крупным хищником. Между тем, следы погрызов на костях отсутствуют. Это свидетельствует о том, что как минимум часть костей, в т.ч. и человека, была намеренно помещена в полость через круглое отверстие в стене. Возможно, что эта трещина была заложена камнями и следами этого действия являются два крупных камня, застрявших в трещине (рис. 15).

\section{Обсуждение}

\section{Общие замечания}

Человеческие останки были обнаружены в двух первых залах темной части пещеры - Сталагмитовом и Купольном. Основное скопление останков человека было обнаружено в Купольном зале, отделенном от остальной части пещеры низким переходом и тепловым барьером. Присутствует качественное отличие в характере находок в этих залах. Так, в Сталагмитовом зале зафиксировано два пункта находок: целый череп (№ 1) у правой стены и фрагменты черепной крышки и верхней челюсти (№2) в небольшой нише у левой стены. В Купольном зале найдены два целых черепа человека (№№ 3 и 5), фрагменты черепов и других костей человека. Возможно, что часть останков человека оставлялась на поверхности пола, а часть - именно черепа, выставлялись в нишах с культовыми целями. Об этом же могут свидетельствовать и следы скальпирования и очищения от мягких тканей черепов, что говорит о намеренной их обработке перед выставлением(?) внутри пещеры.

В ходе раскопок в Купольном зале (раскоп 1) были выявлены три культурных слоя эпохи голоцена. К первому относятся находки с поверхности и до глубины 5 см. Второй культурный слой (от 5 до 10 см от поверхности) содержал кости животных,и целый череп человека (№ 5), он подстилался слоем кальцитового натека. В культурном слое 3 были обнаружены кости диких и домашних животных вместе с единичными костями человека, а также следы кострищ. Все это может указывать на неоднократное проведение в течение продолжительного времени в дальней части пещеры (в Купольном зале) обрядов, связанных с демонстрационным выставлением и манипулированием человеческими черепами, включающих использование их фрагментов в каких-то ритуальных (?) трапезах.

Очевидно, черепа и другие фрагменты скелета были принесены в пещеру Шульган-Таш (Каповую) и некоторые человеческие кости использовались во внутренних залах как ритуальные предметы. Черепа могли быть выставлены у стен как демонстрационные объекты, оформляющие сакральное пространство древнего святилища. Это также подтверждается тем, что в раскопах В.Г.Котова и В.С.Житенева кости человека представлены, в основном, черепами и их фрагментами, ${ }^{6}$ остальные находки являются колотыми костями диких и домашних животных (фрагменты черепов - медведь, лошадь, свинья/кабан, ребра - мелкий рогатый скот), чешуей рыбы и следами кострищ. Принципиально важным является вывод о том, что концентрация находок резко возрастает в северо-восточном направлении, т.е. к цент-

${ }^{6}$ В.Г. Котов допускает, что часть костей в раскопе 1 может являться человеческими ребрами [Котов, 2010б. С. 15], но имеющиеся определения этого не подтверждают. 


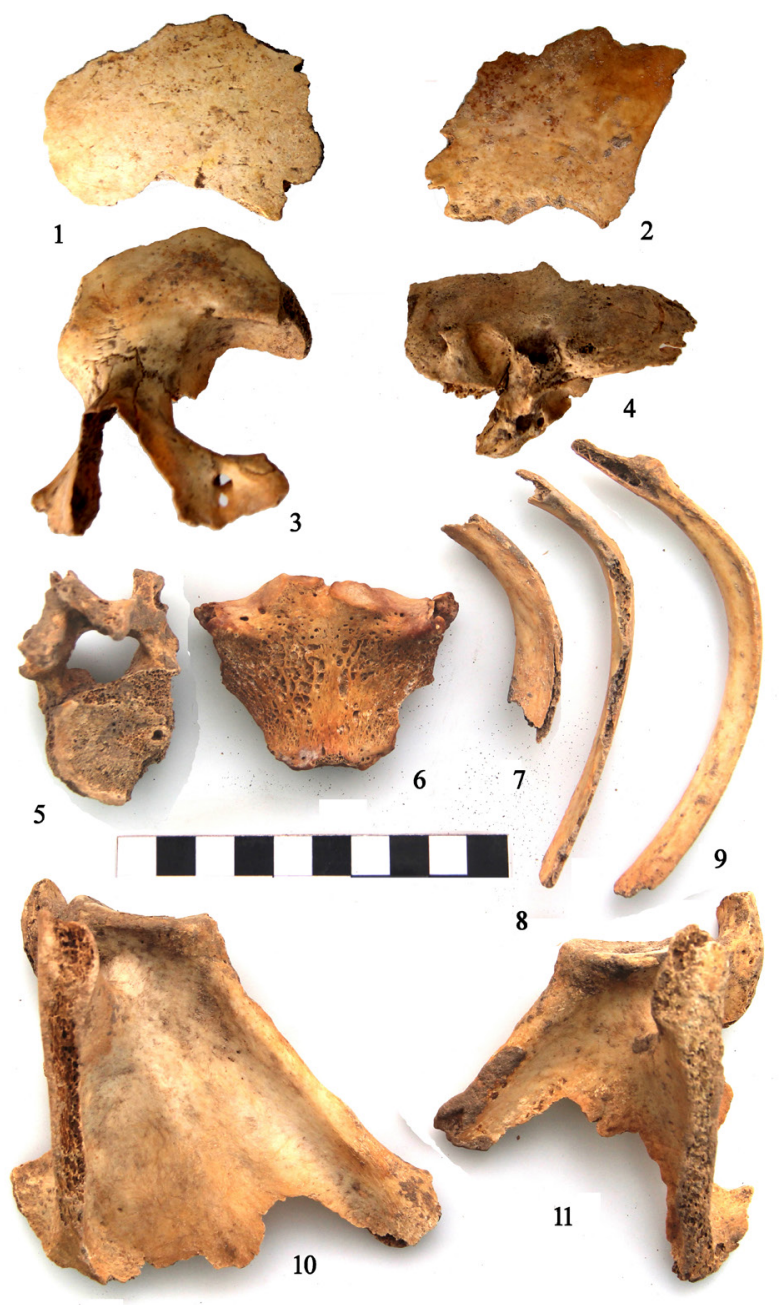

Рис. 16. Пещера Шульган-Таш (Каповая). Зал Купольный, Капелла Черепов. Кости человека из расщелины. Фото В.Г. Котова, 2020 г.

Fig. 16. Shulgan-Tash (Kapova) cave. Dome hall, Skull Chapel. Human bones from the cleft. Photo by V. Kotov, 2020

ру Купольного зала, а черепа №5 и 6 находились фактически уже за пределами этого пятна культурного слоя [Житенев, 2014. С. 116-118. Рис. 2]. Это позволяет говорить о том, что «демонстрационные объекты» находились вокруг центральной площадки, где в сильно золистом слое найдены многочисленные кости животных. К единичным находкам в пределах этой площадки относятся фрагменты керамики, отдельные зубы человека7 и упоминаемая В.С.Житеневым раковина [Житенев, 2014. Рис. 2, 12].

Разнообразие действий, производимых с костными останками человека, которые могли иметь с большой долей вероятности некий сакральный смысл, ставит задачу понять их характер. Следует обратить внимание на то, что два целых черепа (№3 и 5) принадлежали молодым женщинам и имеют сходные следы повреждений, которые могут указывать на преднамеренность насильственных действий, совершенных над ними.

На примере фрагментов черепа №4 из Купольного зала был установлен факт посмертного скальпирования и очищения от мягких тканей. Это может указывать на преднамеренную подготовку черепов человека для неких ритуалов. Кроме того, кости человека специально помещались под навесы стен в нишах и в трещинах. Вместе с тем, следы от рубящих ударов металлическим орудием и другие факты преднамеренной фрагментации черепов говорят о том, что с ними производились разнообразные манипуляции, которые также могли иметь ритуальный характер. Например, фрагментирование некоторых черепов человека могло быть связано с необходимостью их помещения в расщелину Капеллы Черепов Купольного зала. Отверстие круглой формы, находящееся в укромной нише на высоте чуть больше 1 м от современной поверхности, могло восприниматься древним населением как символическое лоно Матери-Земли и помещение в него костей человека и животных - это ритуальное действие по возрождению-реинкарнации умерших в будущем.

Одним из элементов этих обрядов могло являться вкушение пищи во внутренних залах пещеры Шульган-Таш с помощью «черпака» из фрагмента человеческого черепа (№4). О том, что в Купольном зале проводились какие-то обряды, связанные с приготовлением пищи, свидетельствуют находки костей животных, угли и фрагменты глиняных сосудов со следами нагара.

Культурная принадлежность

Для обсуждаемых материалов из Каповой пещеры мы имеем две четкие культурно-хронологические привязки - фрагменты керамики, совершенно верно отнесенные автором раскопок к межовской культуре [Житенев, 2012. С. 158; 2014. С. 118-119. Рис. 3] и две калиброванные ${ }^{14} \mathrm{C}$ даты (Poz-107851, NSKA-01923) по углям из условного горизонта 3, дающие хронологический интервал XIV-XI вв. дон.э.

Судя по опубликованным фотографиям и кратким описаниям, все фрагменты, возможно, относятся к одному сосуду с хорошо профилированным туловом и шейкой, пологим треугольным валиком и каннелюрами на шейке и примесью дробленой раковины в тесте. Сосуд орнаментирован по тулову многорядным горизонтальным зигзагом, нанесенным гладким штампом, по шейке - наклонными пересекающимися отрезками (рис.17). По этим характерным признакам керамика, найденная в пещере, относится к межовской культуре Южного Приуралья, а ближайшими памятниками могут быть названы поселения Тюбяк, Юмагузинское I и Максютово II [Обыденнов, 1988. Рис. 65-68]. Ранее уже отмечалось, что небольшое поселение Максютово II может рассматриваться как единственный «удаленный в горы (60 км по течению р.Белая или 25 км по прямой к востоку от края гор) форпост приуральского лесостепного населения» [Древности..., 2018. С. 45, 199, 200]. Поселения Юмагузинское I и Тюбяк расположены на равнине, соответственно в 20 и 40 км от края

\footnotetext{
7 Зубы человека могут быть и проявлением посвятительного ритуала, предполагающего выбивание зуба у неофита (прим.
} В.Г. Котова). 

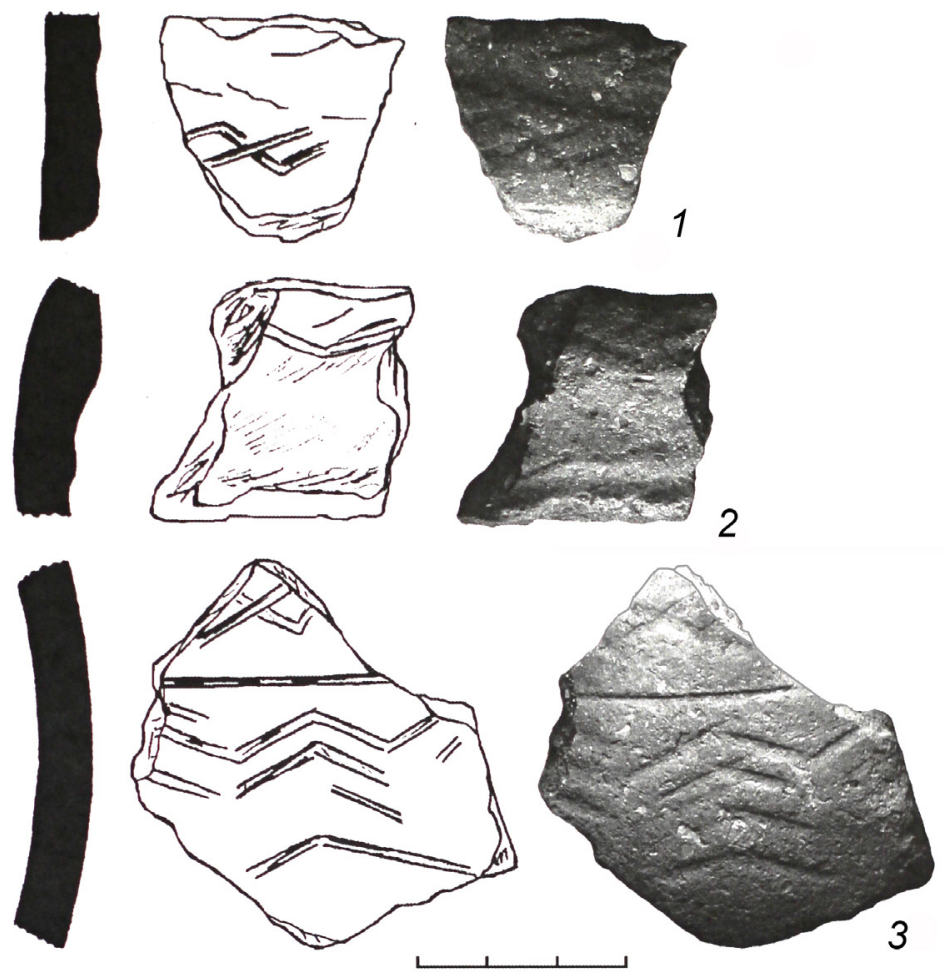

Рис. 17. Пещера Шульган-Таш (Каповая). Зал Купольный. Раскоп МГУ (рук. В.С. Житенев). Фрагменты межовской керамики (по: [Житенев, 2014])

Fig. 17. Shulgan-Tash (Kapova) cave. Dome hall. MSU excavation (the head V. Zhitenev). Pottery fragments of the Mezhovskaya culture (after: [Zhitenev, 2014])

гор и только второе было относительно крупным базовым поселком [Тюбяк.., 2001. С.17. Рис. 7; 8; Русланов, 2018. С. 161-163]. Вероятно, именно его насельники и осваивали достаточно широкую полосу края гор с единичными поселенческими памятниками. Поселение Максютово II расположено в 10 км юго-западнее пещеры Шульган-Таш (Каповая), что составляет 25 км вниз по течению реки, на небольшом мысовидном выступе правого берега р. Белая и окружено залесенными горами.

Детальное археологическое обследование окрестностей пещеры Шульган-Таш, а также имеющиеся данные по памятникам от нее и вплоть до выхода р.Белая из гор показывают полное отсутствие на этом 100-километровом отрезке реки иных приуральских межовских материалов [Древности..., 2018. С. 86-107. Рис. 1.23; 2.12; 2.82]. На отдельных памятниках этой территории (Ташмуруновский грот, селище Атиково-3, поселение Азануй) фиксируются небольшое количество зауральской черкаскульско-межовской керамики, отличающейся от приуральской примесью в основном талька, а не толченой раковины [Котов, Савельев, 2003. С. 126, 127. Рис. 5, 11; Гарустович, Савельев, 2004. С. 110. Рис. 12-13]. Единственный же в горном течении р. Белая памятник межовской культуры, по своему керамическому комплексу относящийся именно к лесостепи Южного Приуралья - это упоминавшееся поселение Максютово II [Обыденнов, 1998. С. 17-18. Табл. 4]. Приведенные данные позволяют рассматривать святилище с человеческими останками в пещере Шульган-Таш как принадлежащее населению межовской культу- ры, проживавшему на поселении Максютово II, в 25 км ниже по течению реки. Очень предварительно и условно может быть намечена и территориальная связка «Тюбяк - Максютово II - ШульганТаш», где первый памятник - базовое поселение в предгорной лесостепи, второй - удаленный в горы небольшой поселок, а третий - еще более удаленное в горы святилище, дальше которого в долине р. Белая не известно ни одного памятника межовской культуры [Савельев, 2011].

\section{Вопросы хронологии}

Говоря о хронологии рассматриваемого комплекса, необходимо учитывать несколько важных моментов:

1)угли, из которых получены две даты $3020 \pm 30$ (Poz-107851) и $3140 \pm 59$ (NSKA-01923), происходят из условного горизонта 3 раскопа 2009 г. (ИИЯЛ УФИЦ РАН), т.е. они относятся к т.н. «культурному слою 3 », подстилающему культурный слой 2 с черепом человека, которые разделены слоем кальцита (рис. 10,Б);

2) в связи с отсутствием в раскопе ИИЯЛ УФИЦ РАН крупных углей, чем он резко отличался от заполнения, выявленного в раскопе экспедиции МГУ [Житенев, 2012. Рис. 9], для датирования собирались все мелкие угольки, найденные в пределах условного горизонта 3, т.е. данные образцы являются сборными;

3) керамика межовской культуры, найденная в раскопе экспедиции МГУ, происходит из верхней части культурного слоя [Житенев, 2012. Рис. 8; 9];

4) расстояние между местом отбора проб для ${ }^{14} \mathrm{C}$ датирования и местом находки керамики со- 
ставляет не более 1,5-2,2 м, т.е. они относятся к одному археологическому объекту - к насыщенному костями животных т.н. «скоплению золисто-углистой массы», при этом место отбора проб приурочено к его периферии, а керамика найдена ближе к его центру;

5) все зафиксированные в пещере человеческие черепа (№№ 1-9; учитывая и небольшие найденные их фрагменты), найдены в разных условиях - на поверхности, с небольшим и относительно небольшим заглублением, в слое кальцитового натека (напр., череп №3 выступал на поверхности на $6 \mathrm{~cm}$ ) и под ним;

6) раскоп экспедиции МГУ в Капелле Черепов четко показал, что культурный слой с керамикой был перекрыт кальцитовым натеком [Житенев, 2014. С. 118].

Bсе эти данные позволяют предполагать значительную условность полученных дат, их разновременность с найденной керамикой и значительную (в пределах нескольких столетий?) продолжительность существования святилища в Купольном зале, на котором производились различные манипуляции с человеческими черепами.

М.Ф. Обыденнов, являвшийся основным исследователем межовской культуры, относит ее сложение к XII-XI вв. дон.э. [Обыденнов, 1998. C. 41,42$]$. Учитывая же наличие в Зауралье переходной черкаскульско-межовской керамики и серии калиброванных радиоуглеродных дат, вызревание характерных черт межовского керамического комплекса может относиться к более раннему времени (XIV-XIвв. дон.э.) [Алаева, 2015. Рис. 1; Лыганов, Морозов, Азаров, 2019. С. 60-64; Епимахов, Петров, 2021. С. 72, 76, 77]. Достаточно ранняя дата появления межовского населения в Приуралье (к сожалению, без какойлибо детализации) определяется по жилищу 1 поселения Тюбяк, на позднем этапе существования которого межовская керамика встречается совместно со срубной [Тюбяк..., 2001. С.17, 133]. При этом вся керамика межовской культуры имеет примесь дробленой раковины [Обыденнов, 1998. Табл. 4]. Иная ситуация прослежена на поселении Юмаково-2, расположенном в 70 км к западу от пещеры Шульган-Таш и в 35 км к северу от поселения Тюбяк, у западного края Уральских гор. Здесь в переделах постройки срубной культуры найдены фрагменты (в том числе и полные развалы) 13 сосудов межовской культуры с примесью талька [Русланов, 2015. С. 184, 185. Рис. 4, $1-4,6-12]$.

Основное время существования межовских памятников в лесостепи Южного Приуралья приходится на XI-IXвв. дон.э. [Обыденнов, 1998. С.44]. Важно, что межовский курганный могильник Красногорский-1, находящийся вместе с поселением Юмаково-2 в составе Береговского микрорайона, по металлическим изделиям дает дату конца X - IX вв. дон.э. [Русланов, 2015. С. 181-184], а вся керамика имеет примесь рако- вины и орнаментирована исключительно резными линиями и гладким штампом [Горбунов, Обыденнов, 1980. С. 181. Рис. 3, 3, 5, 7; 5].

По мнению М.Ф.Обыденнова, самые поздние материалы межовской культуры в горно-лесной зоне Южного Урала датируются VIII-VIIвв. до н.э. [Обыденнов, 1998. С. 45]. Судя по керамическому комплексу, одним из таких поздних памятников является и поселение Максютово II. Его особенность - в наличии сосудов, сочетающих традиции межовской и курмантауской орнаментальных схем, что позволяет доводить существование межовского населения на нем как минимум до VII-VIвв. дон.э. [Савельев, 2018. С.31-32; Древности..., 2018. С.199-200]. Данная линия развития фиксируется практически на всех курмантауских памятниках, исследовавшихся хотя бы относительно крупными раскопами (Азануй-1, Акаваз-1, Сакаска-1 и др.) [Савельев, 2018. С. 33. Рис. 3;6]. Очень важно наблюдение, что на керамике появившегося немного позже в горном течении р.Белая гамаюнского населения присутствуют следы активного курмантауско-гамаюнского взаимодействия, но при этом полностью отсутствуют следы взаимодействия с межовским населением. Имеющиеся хроноиндикаторы и совмещение их с данными, полученными по керамике, позволяют отнести период курмантауско-гамаюнского взаимодействия ко времени не ранее VI-Vвв. дон.э. [Древности..., 2018. С. 53-55, 200, 201. Рис. 1.47; 1.48; 2.42].

В 2020г. в труднодоступной пещере Жемчужная, которая расположена в 1 км вниз по течению р. Белая от Каповой, был сделан ряд находок, которые позволяют уточнить возможные хронологические рамки проведения в последней обрядов с человеческими останками. К ранее найденным в ней бронзовым и костяным наконечникам [Древности..., 2018. С. 100, 101. Рис. 2.42] добавились еще несколько бронзовых наконечников стрел, наконечник копья и кельт. По наличию во втулках кельта и наконечников остатков древок, можно говорить о том, что в пещеру попадали именно стрелы, копье и топор-кельт. Рядом с ними, в тех же голоценовых отложениях, была найдена нижняя челюсть человека [Котов, 2021]. Если первые находки были отнесены к VII-VIвв. дон.э., то находки 2020г. - в первую очередь, наконечники стрел сложившегося «савроматского» облика, - позволили расширить эту дату до VI-V вв. до н.э. Святилище в пещере Жемчужная предположительно (в связи с отсутствием находок керамики) относится к местному населению гамаюнской культуры, плотно осваивавшему в середине I тыс. до н.э. всю округу Шульган-Таша [Древности..., 2018. С. 86-88. Рис. 2.12]. Вероятно, в этих двух пещерах мы наблюдаем проявления одного и того же обряда, основывающегося на манипуляциях с человеческими черепами (в меньшей степени - с костями посткраниального скелета). Это говорит о сохранении у населения 
раннего железа почитания пещер и обрядов жертвоприношений, в том числе, человеческих, хозяину горы/пещеры.

Таким образом, проведенный анализ показывает значительную длительность существования святилища с человеческими останками в пещере Шульган-Таш (Каповой) и вероятную его датировку в пределах X/IX - VI/V вв. дон.э. Имеющиеся радиоуглеродные даты либо отражают самый начальный этап функционирования святилища, либо они удревнены из-за описанного выше «сборного» характера образцов.

\section{Ландиатфно-стратиграфические данные}

В раскопе экспедиции МГУ 2009г. выявлен факт перекрывания части центральной площадки святилища («скопления золисто-углистой массы») толстым слоем кальцитового натека и впаивания находок верхней части культурного слоя в его подошву [Житенев, 2014. С. 118]. Также толстым слоем кальцита покрыты и два черепа -3 и 5. Это свидетельствует о том, что отдельные этапы существования святилища связаны с резкими и длительными увлажнениями, что приводило внутри полости пещеры к постоянной капели, формированию застойных водоемов и заболоченности.

Достаточная обследованность территории вокруг пещеры (около $6 \times 4$ км, протяженность по реке порядка 8 км) позволяет провести корреляцию данных, полученных в пещере, с открытыми поселенческими памятниками. Особенность топографии ближайшей округи Шульган-Таша - крайне незначительное развитие надпойменных террас, прижатых небольшими язычками к окружающим горам, широкое развитие высоких пойм и грив между разновозрастными старицами [Древности..., 2018. С. 86]. Памятники эпохи бронзы здесь достаточно редки (их 4, относятся к алакульской культуре), расположены на участках надпойменных террас, а также на высоком горном плато. Все они являются крайне небольшими стоянками с бедным культурным слоем, на ближайшем памятнике - поселении Шульганово-1, расположенном в 1,7 км к юго-востоку от пещеры - найден только 1 фрагмент керамики эпохи бронзы [Древности..., 2018. С. 102].

Совершенно иная картина прослежена для памятников эпохи раннего железа (в основном курмантауской и гамаюнской культур) окрестностей пещеры - они есть на высоком плато (1), на язычках надпойменных террас (7), а также на ровных участках и гривах высоких пойм (4). В трех случаях (стоянки Шульганово-2, -3 и Ново-Акбулатово-1) тонкая прослойка гумуса, содержащая керамику эпохи раннего железа, перекрыта 50-70-сантиметровым слоем намывного аллю- вия, который заканчивается современным дерном [Древности..., 2018. Рис. 2.47; 2.48]. Такой же аллювий подстилает и гумусную прослойку. Это свидетельствует о том, что в курмантауско-гамаюнское время (VII-Vвв. до н.э.), характеризующееся минимумом обводненности, на заливных поймах начинает формироваться луговая почва, но уже в середине - начале второй половины Ітыс. до н.э. ситуация резко меняется. Вышележащая толща аллювия свидетельствует о значительном увеличении водности всего горного течения р. Белая в последующее время вплоть до этнографической современности [Савельев, 2015. С. 76] и постоянных высоких паводках. Аналогичная гидрологическая ситуация была здесь и во II тыс. до Н.э.

Эти независимые данные позволяют говорить о том, что перекрытие кальцитовой коркой центральной площадки святилища в Купольном зале началось еще в первой половине I тыс. до н.э. Входная же часть пещеры (Главная галерея) с этого времени, скорее всего, представляла собой очень длинное и топкое болото со стоячей водой. Судя по малой мощности погребенных черноземов на пойменных стоянках, период усыхания был относительно недолговременный и только в это время было возможно создание и функционирование в пещере Шульган-Таш (Каповой) святилища. ${ }^{8}$

\section{Использование человеческих черепов \\ и манипуляции с ними: общчие данные \\ и прямые аналогии}

В памятниках эпохи раннего железа Южного Урала единично известны находки емкостей из человеческих черепов. Например, такая происходит из кургана гороховской культуры «Елесина яма» в Юргамышском районе Курганской области, известна и находка чаши из человеческого черепа с серебряными накладками близ д. Салихово в Ишимбайском районе Башкортостана, которая датируется первыми веками нашей эры [Гарустович, 2010. С. 17]. В одном из скальных святилищ на берегу Шайтанского озера (Среднее Зауралье) найдены чаша из черепа человека и череп женщины со следами бронзовых украшений, связываемые автором исследований с иткульской культурой [Сериков, 2013. С. 151]. В 150 км южнее, на оз. Травакуль, между валунами на скальном гребне была установлена чаша из человеческого черепа, рядом с которой найдены кремневый отщеп и клад конской сбруи первой половины I тыс. до н.э. [Васина, Таиров, 2016]. Также в сарматских погребениях Южного Урала встречаются бляхи, изготовленные из человеческих черепов - в кургане №3 Бишунгаровского могильника и в кур-

${ }^{8}$ По мнению В.Г.Котова, фиксируется как минимум три последовательных этапа использования святилища. Начальный этап завершился перекрытием кальцитовой коркой его центральной площадки. Следующий этап использования пещеры в культовых целях был связан с периодом кратковременного усыхания, с которым было связано помещение в зале Купольном черепов № 3,5 и образование культурного слоя 2. Вслед за этим началось увлажнение и образовался слой кальцита, после чего опять наступил относительно кратковременный период аридизации и возобновились обряды человеческих жертвоприношений (культурный слой 1). Этот последний этап может быть сопоставлен с периодом усыхания середины Ітыс. до н.э. По мнению Н.С. Савельева, объективные естественно-научные данные для такого дробного деления отсутствуют, но при этом святилище, несомненно, продолжало существовать в течение нескольких столетий. 
гане № 1 Сибайского I могильника [Пшеничнюк, 1983. С.77. Табл. XV, 2; Мажитов, Пшеничнюк, 1977. Рис. 2, 1]. Хорошо известны и факты скальпирования черепов с обрядовыми целями у ранних сармат Подонья [Перерва, Лукьяшко, 2011. С. 195-196].

Геродот, описывая скифов и их восточных соседей, отмечает широкое бытование среди воинов обычая изготовления из черепов своих врагов сосудов для ритуальных пиршеств [Геродот. IV. 64-65, 26]. Подобная практика использования человеческих черепов известна как минимум со II тыс. до н.э. (курган у с. Олонешты на Днестре) и была широко распространена у многих народов Евразии вплоть до средневековья [Гарустович, 2010. C. 20].

Все это единичные и порой достаточно удаленные свидетельства. Но на Южном Урале есть как минимум одна прямая аналогия обсуждаемому комплексу из Шульган-Таша - это Игнатиевская пещера [Петрин, 1992]. Сводя воедино все разрозненные сведения, опубликованные В.Т.Петриным, авторами приложений к этой монографии и В.С.Житеневым, собравшим дореволюционные данные [Житенев, 2011. С.466-468], мы можем реконструировать следующую картину. П.С. Паллас, С.И. Руденко, О.Н. Бадер, т.е. все, изучавшие пещеру до начала в ней планомерных работ (1980-1986 гг.), находили человеческие останки - черепа, отдельные кости посткраниального скелета, есть упоминание о «почти полном скелете», но все они лишены какого-либо археологического контекста и могут датироваться вплоть до Нового времени. Принципиально важные данные были получены в Игнатиевской пещере именно в 1980-егг.

В Низком переходе (60 м от входа в пещеру, длина 10 м, максимальная ширина 10 м, высота до $1-1,5$ м, фиксируются следы углубления прохода в древности примерно на 0,4 м) расположенном уже в зоне пещерного микроклимата, на границе слабо освещенной и совершенно темной частей пещеры, в раскопе IV (1983 г,, размер $3 \times 1$ м) был расчищен детский череп. Он находился в средней части Низкого перехода, в низкой щели, где край рыхлых отложений смыкается со сводом потолка, за искусственным навалом камней [Петрин, 1992. Рис. 10; 77]. Череп ребенка 6-7 лет был уложен на уровне верха палеолитического культурного слоя и был сильно разрушен капелью [Чикишева, 1992. С. 197], т.е. он долгое время находился в открытом виде. Впоследствии череп зарос гумусированным серым слоем и верхушка черепа практически находилась на уровне современного пола. Непосредственно вокруг (на участке $0,5 \times 0,5$ м) этого черепа сконцентрирован максимум костных находок (36 экз.) из данного раскопа [Петрин, 1992. C. 99-100], из них порядка десятка являются разрозненными фрагментами человеческих костей, а две находились внутри черепа ребенка (одна со следами рубки) [Чикишева, 1992. С. 197-198]. Больше в раскопе не найдено ни одной (!) кости человека, что говорит о преднамеренности создания всего комплекса - как размещения черепа ребенка, так и обрубков костей взрослых индивидов, в том числе и вырубленного куска верхней челюсти с сильно стертыми зубами. Определение остальных костей показало наличие в данном раскопе фрагментированных костей овцы, косули, зайца и барсука [Косинцев, 1992. С. 184-185]. Керамика в раскопе полностью отсутствует.

Данные по раскопу IV очень хорошо дополняются детальными поверхностными сборами, проводившимися в Игнатиевской пещере. Установлено, что осадконакопление во внутренней части пещеры, в том числе и в Низком переходе, прекратилось на рубеже плейстоцена и голоцена. Но при этом Низкий переход - самое дальнее место в пещере, где сформировался тонкий культурный слой голоценового времени. Фактически это слабо прокрашенный разреженный «слой посещения» поверхностного залегания, сформированный прямо на палеолитическом слое с сохранившимися очень хрупкими копролитами пещерных медведей. При этом, из поверхностных сборов кости домашних животных (11,3\%) найдены только в Низком переходе [Косинцев, 1992. Табл.9]. Также в нише уже Основного коридора, напротив Низкого перехода найден череп барсука с нижней челюстью голоценовой сохранности [Косинцев, 1992. С. 183]. Распределение находок керамики показывает, что, помимо входной части, что вполне закономерно, участком очень высокой концентрации является маленький, небольшой и крайне неудобный отдел Игнатиевской пещеры - Низкий переход, где все находки представлены исключительно керамикой межовской культуры с примесью раковины [Шорин, 1992. С. 198].

Таким образом, в Низком переходе Игнатиевской пещеры фиксируются демонстрационные комплексы из черепов ребенка и барсука (также, возможно, к ним относится и упоминаемый П.С. Палласом детский череп за крупным камнем в Правом гроте, т.е. прямо перед началом Низкого перехода [Житенев, 2011. С.466]), связанные с концентрацией углей [Петрин, 1992. Рис. 77] и расположенные в нишах. К черепу ребенка приурочены различные обрубки костей людей взрослого возраста, а также высокая концентрация находок костей животных, в том числе и домашних. Единственная возможная синхронизация этого комплекса - межовская культура эпохи финальной бронзы. Все это вплоть до мелких деталей имеет аналогии в Капелле Черепов пещеры Шульган-Таш (Каповая). Избирательное, т.е. явно ритуальное, попадание черепов барсука и медведя в культурный слой охотничьего памятника эпохи бронзы зафиксировано в Ташмуруновском гроте, находящегося недалеко от пещеры Шульган-Таш. В нем было найдено скопление из четырех черепов барсука с нижними челюстями, трех черепов взрослых и трех черепов молодых особей бурого медведя, а также черепа взрослого бобра, при этом от барсука в грот попадали в основном 
только головы. Рядом с гротом находилась отдельная ниша с медвежьими черепами [Котов, Савельев, 2003. С. 135. Рис. 2; Косинцев, 2003. С. 156, $159,162]$. А верхняя челюсть человека со следами вырубания из черепа, найденная в Игнатиевской пещере, хорошо корреспондируется с т.н. «воинскими трофеями» населения рубежа эр лесостепи Нижней Белой, Прикамья и Западного Поволжья [Зубов, 2007. С. 79. Рис. 6].

Возможно, что подобный же комплекс был зафиксирован и во 2-й Серпиевской пещере, расположенной на р. Сим примерно в 13 км вверх по течению от Игнатиевской пещеры. Здесь во входной части найдены кости мужчины 25-35 лет, при этом «все фрагменты посткраниального скелета мужчины отрублены», а немного вглубь пещеры - лицевой отдел черепа женщины возрастом 1820 лет [Петрин, Широков, Чаиркин, 1990. С. 19. Рис. 2].

Все приведенные данные четко позволяют локализовать ближайшие аналогии рассматриваемому комплексу в пещере Шульган-Таш (Каповой) в пределах гор и предгорий Южного Урала, и связать с местным межовским и, вероятно, родственным, но немного более поздним, эпохи раннего железа, населением этой территории (гамаюнской, иткульской культуры, носителей керамики гафурийского культурного типа и пр.). Практически вся средняя полоса Южного Урала (широта Уфа - юг Месягутовской лесостепи - Златоуст - Челябинск) по долинам Ая, Сима, Юрюзани и других рек изобилует пещерами с многочисленными материалами эпохи раннего железа, но они до сих пор полноценно не введены в научный оборот [Савельев, 2004; Боталов, 2016. Рис.6, $4,9,11,34,35,40 ; 19,4,7,8]$. Во многих из них присутствуют разрозненные человеческие кости [см. напр.: Житенев, 2011. С.470-471]. Вероятно, комплекс, выявленный в Шульган-Таше, благодаря длительности, детальности и тщательности проводимых работ, на данный момент является самым изученным и максимально собранным. Но при этом он показывает ординарность такой ритуальной практики для населения гор и предгорий Южного Урала эпохи финальной бронзы и раннего железа.

\section{Реконструкичя обрядового комплекса}

Предложенная В.С.Житеневым интерпретация комплекса находок в Сталагмитовом и Купольном залах пещеры Шульган-Таш (Каповой) как места поверхностных вторичных (экскарнационных) захоронений [Житенев, 2012. С. 158] основывается на ярких данных О.Н.Корочковой по зольникам Зауралья и Западной Сибири. Они являются практически обязательным атрибутом поселений эпохи поздней и финальной бронзы и на ряде из них найдены скопления человеческих костей, очищенных от мягких тканей [Корочкова, 2009. С. 25-34]. Однако, интерполировать эти данные на находки, сделанные в «скоплении золисто-углистой массы» на границе Капеллы Черепов Купольного зала нельзя: большое количество ко- лотых костей животных, в том числе и от черепов, отсутствие сколько-нибудь достаточного количества человеческих костей, их упорядоченности и пр. - все это свидетельствует о совершенно ином характере выявленного объекта. В рассматриваемом случае, вероятно, принципиальной связкой является пара «центральная площадка» - «рассредоточенное вокруг нее расположение черепов с очень малым участием костей посткраниального скелета».

Ближайший к пещере Шульган-Таш (Каповой) Красногорский I курганный могильник показывает, что межовское население практиковало как стандартную ингумацию, так и т.н. «вторичные погребения» (более 1/3 всех захоронений могильника). Среди них есть практически полные скопления костей, собранные кучкой, поверх которой положен череп, а есть погребения, состоящие из черепа и буквально единичных костей [Горбунов, Обыденнов, 1980. С. 173-179]. Вероятно, у населения межовской культуры Южного Приуралья также существовали внутрипоселенческие зольники типа Ново-Шадринского [Корочкова, 2009. Рис. 4], происходила селекция очищенных костей и т.д. Судя по всему, какая-то часть умерших либо приносимых в жертву людей, не хоронилась на общих кладбищах, а попадала вглубь пещер, где с их костями проводились всевозможные и достаточно длительные манипуляции.

Тот факт, что сходным образом было организовано ритуальное пространство и в других пещерах Южного Урала (размещение ритуальной площадки на границе света и тьмы, в низком переходе, демонстрационное выставление черепов человека и животных, разрубание на части костей и черепов человека и животных, ритуальные трапезы внутри пещеры, огонь, различные приношения), а также аналогии на памятниках эпохи финальной бронзы - раннего железа на соседних территориях, указывают на существование единого мифологического контекста данной обрядности. Это позволяет в поисках объяснения рассматриваемой ритуальной практики обратиться к фольклорному материалу.

Прежде всего, весь описываемый комплекс обрядовых проявлений в пещерах Шульган-Таш и Игнатиевской находит полное соответствие с обобщенным образом «избушки Бабы-Яги», анализ которого был сделан В.Я. Проппом. «Баба-Яга - костяная нога» - людоедка, ее избушка на курьих ножках находится на границе с потусторонним миром и является входом в мир мертвых [Пропп, 1986. С.62]. Животный облик избушки дополняется оформлением человеческими костями и черепами [Пропп, 1986. С. 63]. Перед тем, как получить от Бабы-Яги новое знание, неофит должен был вкусить пищи и тем самым приобщиться к миру мертвых и преобразиться [Пропп, 1986. С.67]. В связи с этим, в некоторых сказках присутствуют мотивы пребывания неофита во тьме, отверзание глаз и получение нового зрения [Пропп, 1986. С. 74]. В лесной избушке детей разруба- 
ют на части, заново собирают и оживляют [Пропп, 1986. С. 97]. Разрубание на части неофита, как метафора временной смерти, широко представлено как в фольклоре, так и в этнографии традиционных народов в ритуалах, связанных с обрядом посвящения. В обрядах инициации у традиционных народов нередко вместо неофита проводилось заместительное разрубание другого человека или животного, причем и в шаманской мифологии разрубание на части неофита являлось непременным условием превращения его в шамана [ПропП, 1986. С.94-95]. В итоге В.Я.Пропп приходит к выводу о том, что фольклорный образ избушки Яги сохранил характеристики священного места для проведения обрядов посвящения-инициации, a сама старуха имеет черты Хозяйки природы и повелительницы зверей [Пропп, 1986. С. 75, 111].

Анализ башкирского фольклора также показывает наличие у древнего южно-уральского населения женских демонических персонажей двойственной природы, выступающих как помощники или противники героя, что сближает их с образом Бабы-Яги восточнославянского фольклора [Башкирские..., 1941. С. 25, 100; БНТ, ІІІ. № 38. С. 369; БHT, IV. C.156-157, 200]. Также присутствует образ старика-наставника, людоеда и похитителя детей, обитателя подземного мира, действия которого с неофитами имеют ярко выраженный инициационный контекст, заключающийся в умерщвлении юного героя, измельчении и последующем преображении его в новом обличье и с новыми знаниями [БНТ, III. С. 186-188, 345-360; БНТ, IV. С. $51-53,96,141]$. В ряде сказок в качестве помощника-советника выступает отрубленная голова или череп человека [БНТ, IV. С.87, 107] и, наряду с этим, зола от черепа, которую нечаянно попробовала девушка, стала причиной зачатия и рождения мальчика с вещими способностями [БНТ, IV. № 75]. Исходя из этого, можно предположить, что данные образы являются отголосками неких посвятительных ритуалов, происходивших в подземном мире. Выделенные нами образы и мифологемы являются лишь элементами достаточно внушительного пласта южно-уральской мифологии посвятительного характера, сохранившейся в башкирском фольклоре [Котов, 1997].

Детальное сходство ритуальной практики эпохи финальной бронзы - раннего железа внутри пещерных святилищ Южного Урала с обрядово-мифологическим содержанием фольклорных образов дает основание предполагать, что эти обряды имели посвятительный характер.

\section{Заключение}

То, что костные останки человека приурочены к первым двум залам темной части пещеры на достаточно большом расстоянии от входа (120 150 м), а также то, что некоторые черепа специально выставлялись в нишах вокруг центральной площадки как демонстрационные комплексы - все это указывает как на организацию сакрального пространства пещеры, так и на восприятие этих залов как некого «преддверия» потустороннего мира, в котором и осуществлялась ритуальная активность людей в эпоху финальной бронзы и раннего железа. Не исключено и достаточно продолжительное пребывание людей в данных залах, которое могло также иметь сакральное значение - но прямые подтверждения этому пока отсутствуют. Напрашивается единственное приемлемое объяснение природе приведенных выше фактов: все они являются проявлениями обрядов инициации и символических приношений «Хозяину пещеры» или Матери-Земле, проводимых в это время пещере Шульган-Таш (Каповой).

Вряд ли случайным является сходство мировоззренческого контекста этих находок с мифологическими представлениями, представленными в архаических эпосах «Урал-батыр» и «Акбузат», сохранившихся у башкирского населения. В них пещера Шульган-Таш и озеро Шульган воспринимаются как центр мифологической картины мира, потусторонний мир, населенный умершими предками [Котов, 2006. С. 268]. Более того, в этих эпосах описываются сцены человеческих жертвоприношений некоему озеру-роднику в честь МатериЗемли (эпос «Урал-батыр») и озеру Шульган (эпос «Акбузат»), причем между этими двумя озерами имеется прямое смысловое тождество [Котов, 2006. С.216-218]. В этих эпосах в жертву приносились молодые девушки, что в эпосе «Акбузат» объяснялось как принесение в жертву невест для хозяина подводного мира - хана Шульгана. Кроме того, в эпосе «Акбузат» озеро Шульган описывается как место пребывание умерших родичей-предков [БНЭ, 1977. С. 403; Котов, 2006. С. 243].

Все эти характеристики озера Шульган следует переносить на восприятие пещеры ШульганТаш, поскольку они в сознании создателей эпоса были слиты воедино. Не случайно о пещере Шульган-Таш у окрестных башкир бытуют предания о том, что внутри живут особенные люди, которые имеют скот и занимаются хлебопашеством [Котов, 2006. С.268]. Таким образом, пещера ШульганТаш воспринималась как зеркальное отражение мира людей, то есть как мир, потусторонний человеческому.

Весь этот комплекс представлений о Хозяине подводного потустороннего мира озера Шульган и пещеры Шульган-Таш основан на архаической, еще охотничьей мифологии, имеющей черты космогонических и инициационных мифов о Хозяине Природы, впоследствии трансформированной в духовной культуре скотоводческого народа. Учитывая их древность и связь с мировоззрением охотников и скотоводов, можно предполагать, что они были тем мифологическим фоном, в связи с которым и осуществлялась обрядовая практика населения самого конца бронзового и начала раннего железного века в пещере Шульган-Таш. А во многих пещерах Уральского региона этого времени существовали своеобразные святилища, напоминающие «избушки Бабы-Яги» восточнославянских сказок, где проводились жертвоприношения, выставления и множество других манипуляций с человеческими останками. 


\section{СПИСОК ЛИТЕРАТУРЫ}

Алаева И.П. Культурно-хронологическая позиция черкаскульско-межовских комплексов Южного Зауралья (по материалам поселения Чебаркуль III) // Древний Тургай и Великая степь: часть и целое. Сб. науч. ст., посвящ. 70-летнему юбилею Виктора Николаевича Логвина / Отв. ред. А.З. Бейсенов. Костанай - Алматы: Институт археологии им. А.Х. Маргулана КН МОН РК, 2015. С. 474-484.

Бадер О.Н. Каповая пещера. Палеолитическая живопись. М.: Наука, 1965. 47 с.

Башкирские народные сказки. Запись и перевод А.Г.Бессонова / Ред., введение, примеч. Н.К.Дмитриева / Ред. И.Ю. Крачковский. Уфа: Башгосиздат, $1941.367 \mathrm{c.}$

БHT, III: Башкирское народное творчество. T.III. Богатырские сказки / Сост. Н.Т.Зарипов. Уфа: Башкирское кн. изд-во, 1988. 448 с.

БHT, IV: Башкирское народное творчество. T.IV. Волшебные сказки. Сказки о животных / Сост. Ф.А.Надршина. Уфа: Башкирское кн. издво, 1987. $512 \mathrm{c}$.

БНЭ: Башкирский народный эпос / Сост. А.С.Мирбадалева, М.М.Сагитов, А.И.Харисов. М.: Наука, 1977. 518 c.

Боталов С.Г. Историко-культурные горизонты раннего железного века и средневековья лесостепного Зауралья // Археология Южного Урала. Лес, лесостепь. Ранний железный век и средневековье (проблемы культурогенеза). Челябинск: Рифей, 2016. С. 468-541. (Этногенез уральских народов)

Васина Ю.В., Таиров А.Д. Скальное святилище на озере Травакуль // Вестник ЮУрГУ. Серия «Социально-гуманитарные науки». 2016. Т. 16. №3. C. 13-20. DOI: 10.14529/ssh160302

Вахрушев Г.В. Загадки Каповой пещеры (Шулган). Уфа: БФАН СССР, 1960. 29 с.

Гарустович Г.Н. Сосуды из голов неприятельских // Родина. 2010. Спецвыпуск. С. 16-20.

Гарустович Г.Н., СавельевН.С. Исследования памятников эпохи бронзы - раннего железного века в горном течении реки Белой (к вопросу об этнокультурных реликтах на Южном Урале) // Уфимский археологический вестник. Вып. 5. 2004. C. 93-118.

Геродот. История. В 9-ти книгах. Перевод и приложения Г.А.Стратановского. М.: Ладомир; ACT, 1999. $752 \mathrm{c}$.

ГимрановД.О. Костные остатки голоценовых млекопитающих из пещеры Шульган-Таш (раскопки 2009г.) // Материалы регион. науч. конф. «Археология в БашГУ: Итоги и перспективы», посвящ. 50-летию археологической экспедиции БГУ. Уфа: РИЦ БашГУ, 2011. С. 70-73.

Горбунов В.С., ОбыденновМ.Ф. Курганный могильник эпохи поздней бронзы в Южной Башкирии // Советская археология. 1980. №3. С. 173182.

Древности Башкирского Урала / Сост. и науч. ред. Н.С.Савельев. Уфа: Информреклама, 2018. $216 \mathrm{c}$.
Епимахов А.В., Петров Ф.Н. Радиоуглеродная хронология культурных традиций бронзового века Зауралья: по материалам поселения Левобережное (Синташта II) // Российская археология. 2021. № 3. C. 67-79.

Житенев В.С. Антропологические материалы из южно-уральских пещерных памятников с настенными изображениями: к постановке проблемы // Палеолит и мезолит Восточной Европы / Отв. ред. К.Н. Гаврилов. М.: Таус, 2011. С. 462-476.

Житенев В.С. Капова пещера - многослойный памятник археологии: предварительное сообщение // Первобытные древности Евразии. К 60-летию Алексея Николаевича Сорокина / Отв. ред. С.В. Ошибкина. М.: ИА РАН, 2012. С. 155-178.

Житенев В.С. Археологический контекст открытия палеоантропологических материалов в пачке голоценовых напластований Каповой пещеры // Вестник Московского университета. Серия XXIII. Антропология. 2014. №2. С. 114-121.

Житенев В.С. Капова пещера - верхнепалеолитическое пещерное святилище с настенными изображениями. Дисс. на соиск. ... докт. ист. наук. Т. 1. Москва, 2017. $441 \mathrm{c.}$

Зубов С.Э. Кипчаковский культурно-хронологический горизонт в системе пьяноборской культуры // Уфимский археологический вестник. Вып. 6-7. 2007. С. 72-88.

КорочковаО.Н. О западносибирских зольниках эпохи поздней бронзы // Российская археология. 2009. № 1. С. 25-35.

КосинцевП.А. Остатки крупных млекопитающих из пещер в верховьях р.Сим // Петрин В.Т. Палеолитическое святилище в Игнатиевской пещере на Южном Урале. Новосибирск: Наука, 1992. C. $178-188$.

КосинщевП.А. Археозоологические материалы из раскопок Ташмуруновского грота в верховьях реки Белой // Уфимский археологический вестник. Вып. 4. 2003. С. 148-162.

Котов В.Г. Мифология Южного Урала (К вопросу о реконструкции хтонических культов). Уфа: Гилем, 1997. $65 \mathrm{c.}$

Котов В.Г. Башкирский эпос «Урал-батыр». Историко-мифологические основы. Уфа: Гилем, 2006. $408 \mathrm{c}$.

Котов В.Г. Феномен пещеры Шульган-Таш (Каповой) // Культурное наследие Южного Урала как инновационный ресурс. Материалы Всерос. науч.-практ. конф. «Природное и культурное наследие Южного Урала как инновационный ресурс». Уфа: ИИЯЛ УНЦ РАН, 2010а. С. 43-69.

Котов В.Г. Научный отчет об исследованиях пещеры Шульган-Таш (Каповая) в Бурзянском районе Республики Башкортостан в 2009г. Уфа, $2010 б$ // Научный архив ИА РАН.

Котов В.Г. Пещерное святилище ШульганТаш (Каповая): структура, следы ритуалов, семантика изображений // Древние святилища: археология, ритуал, мифология. Материалы Междунар. 
науч. симпозиума. Уфа: ИИЯЛ УНЦ РАН, 2016. C. 41-63.

Котов В.Г. Научный отчет об исследованиях пещеры Шульган-Таш (Каповая) в Бурзянском районе Республики Башкортостан в 2015 г. Уфа, 2017 // Научный архив ИА РАН.

Котов В.Г. Научный отчет об исследованиях пещеры Шульган-Таш (Каповая) в Бурзянском районе Республики Башкортостан по Открытому листу № 1361 от 31.07.2017 г. в 2017 г. Уфа, 2019 // Научный архив ИА РАН.

Котов В.Г. Научный отчет об исследованиях объекта культурного наследия федерального значения «Капова пещера с живописью эпохи палеолита» по Открытому листу № 1041-2020 от 16.07. 2020 г. в Бурзянском районе Республики Башкортостан в 2020 г. Уфа, $2021 / /$ Научный архив ИА РАН.

Котов В.Г., Савельев Н.С. Промысловая стоянка «Ташмуруновский грот» в верховьях реки Белая // Уфимский археологический вестник. Вып. 4. 2003. С. 124-147.

ЛыгановА.В., МорозовВ.В., АзаровЕ.С. Луговские I и II стоянки и проблема соотношения черкаскульской, луговской и межовской культур в Нижнем Прикамье // Археология Евразийских степей. №2. 2019. С. 38-98.

Ляхницкий Ю.С. Многолетние исследования пещеры Шульган-Таш (Каповой) группой ВCEГЕИ и РГО, как основа спасения ее палеолитической живописи // Изучение заповедной природы Южного Урала. Вып. 2. Уфа: Вилли Окслер, 2006. C. 331-382.

Мажитов Н.А., ПшеничнюкА.Х. Курганы раннесарматской культуры в южной и юго-восточной Башкирии // Исследования по археологии Южного Урала / Отв. ред. Р.Г. Кузеев. Уфа: БФАН CCCP, 1977. C. 52-56.

Обыденнов М.Ф. Межовская культура. Уфа: БЭК, 1998. $201 \mathrm{c}$.

ПерерваЕ.В., ЛукьяшкоС.И. О семантике обряда скальпирования у ранних сарматов // Погребальный обряд ранних кочевников Евразии. Материалы VII Междунар. науч. конф. (11-15 мая 2011 г. Ростов-на-Дону, Кагальник). Ростов-наДону: ЮНЦ РАН, 2011. С. 193-200.

Петрин В.T. Палеолитическое святилище в Игнатиевской пещере на Южном Урале. Новосибирск: Наука, 1992. 207 с.

Петрин В.T., Широков В.Н., ЧаиркинС.Е. Древнее святилище во 2-ой Серпиевской пещере на Южном Урале // Семантика древних образов (Первобытное искусство) / Отв. ред. Р.С. Васильевский. Новосибирск: Наука, 1990. С. 7-20.

Пещерное святилище Шульган-Таш (Каповая) /Сост. и отв. ред. В.Г.Котов. Уфа: Китап, $2019.360 \mathrm{c}$.

Пропn В.Я. Исторические корни волшебной сказки. Л.: ЛГУ, 1986. 365 с.

ПшеничнюкА.Х. Культура ранних кочевников Южного Урала. М.: Наука, 1983. 200 с.

РуслановЕ.В. Памятники финальной бронзы
Береговского археологического микрорайона // Этнические взаимодействия на Южном Урале. Материалы VI Всеросс. науч. конф. Челябинск: Челябинский гос. краеведч. музей, 2015. С. 181-186.

Русланов Е.В. Поселение Юмагузино-1 // Древности Башкирского Урала / Сост. и науч. ред. Н.С.Савельев. Уфа: Информреклама, 2018. C. 161-163.

РычковП.И. Описание пещеры, находящейся в Оренбургской губернии при реке Белой, которая из всех пещер в Башкирии находящихся за славную и наибольшую почитается // Исследователи-путешественники о Башкортостане. XVIIIв. / Сост. В.В. Сидоров. Уфа: Китап, 2007. С. 15-26.

Савельев Н.С. Горы Южного Урала в эпоху раннего железа // Этнические взаимодействия на Южном Урале. Материалы II регион. науч.-практ. конф. Челябинск: Рифей, 2004. С. 119-122.

Савельев Н.С. Памятники эпохи раннего железа горного течения р. Белая (разведочные работы А.П.Шокурова 1961-1962 гг.) // Наследие веков. Вып. 2. Материалы Регион. науч.-практ. конф. «Историческое краеведение в Башкортостане: история и современность», посвящ. 100-летию со дня рождения краеведа-археолога Анисима Павловича Шокурова. Уфа: ИИЯЛ УНЦ РАН, 2011. C. $42-70$.

Савельев Н.С. Поселенческие памятники кочевников скифо-сарматского времени в южной части горно-лесной зоны Южного Урала // Уфимский археологический вестник. Вып. 15. 2015. C. 62-84.

Савельев Н.С. Памятники гамаюнской и курмантауской культур юго-западной оконечности Уральской горной страны // Уфимский археологический вестник. Вып. 18. 2018. С.24-42. DOI: 10.31833/uav.2018.18.003

Сериков Ю.Б. Шайтанское озеро - священное озеро древности. Н. Тагил: НТГСПА, 2013. 408 с.

Соколов Д., Заневский И., Симон Ф. Протокол об осмотре и измерении Каповой пещеры на р. Белой в Орском уезде Оренбургской губернии, близ д.Шульгановой (Адильгареевой) 3-й Бурзянской волости // Известия Оренбургского отделения Русского географического общества. 1897. Вып. 10. С. 75-79.

Тюбяк: поселение бронзового века на Южном Урале / Науч. ред. В.С. Горбунов. Уфа: БГПУ, 2001. $159 \mathrm{c}$.

Чикишева Т.А. Антропологические остатки из Игнатиевской пещеры // Петрин В.Т. Палеолитическое святилище в Игнатиевской пещере на Южном Урале. Новосибирск: Наука, 1992. С. 197-198.

Шорин А.Ф. Археологические материалы позднего времени (бронзовый век - средневековье) из Игнатиевской пещеры // Петрин В.Т. Палеолитическое святилище в Игнатиевской пещере на Южном Урале. Новосибирск: Наука, 1992. C. $198-205$.

Щелинский В.Е. Палеогеографическая среда и археологический комплекс верхнепалеолитического святилища пещеры Шульган-Таш (Ка- 
повой) // Пещерный палеолит Урала. Материалы междунар. конф. Уфа: Гилем, 1997. С. 29-38.

Юсупов Р.М., Нечвалода А.И. О находке человеческого черепа в пещере Шульган-Таш // Культурное наследие Южного Урала как инновационный ресурс. Материалы Всерос. науч.-практ. конф. «Природное и культурное наследие Южного Ура- ла как инновационный ресурс». Уфа: ИИЯЛ УНЦ PAH, 2010. C. 107-115.

Ščelinskij V.E., Širokov V.N. Höhlenmalerei im Ural: Kapova und Ignatievka; die altsteinzeitlichen Bilderhohlen im sudlichen Ural, 1999. Sigmaringen: Jan Thorbecke Verlag. $171 \mathrm{p}$.

\section{REFERENCES}

Alaeva, I.P. "Cultural and chronological position of the Cherkaskul-Mezhovskaya assemblages from the Southern Trans-Urals region (based on the materials from Chebarkul III settlement)", Drevnij Turgaj $i$ Velikaya step': chast' $i$ celoe (Sb. nauch. st., posvyashch. 70-letnemu yubileyu Viktora Nikolaevicha Logvina) ("Ancient Turgai and the Great Steppe: part and unity (A collection of scientific papers dedicated to the 70th anniversary of birth of Viktor Nikolaevich Logvin)"). Kostanaj - Almaty, 2015, pp. 474-484. (In Russ.)

Bader, O.N. 1965, Kapova cave. Paleolithic art. Nauka, Moscow, 47 p. (In Russ.)

Bessonov, A.G. 1941, Bashkir folk tales. Bashgosizdat, Ufa, 369 p. (In Russ.)

Bashkir folk art. Vol. III. Heroic tales. Bashkirskoe knizhnoe izdatel'stvo, Ufa, 1988, 448 p. (In Russ.)

Bashkir folk art. Vol. IV. Fairy tales. Animal Tales. Bashkirskoe knizhnoe izdatel'stvo, Ufa, 1987, 512 p. (In Russ.)

(In Russ.)

Bashkir folk epics. Nauka, 1977, Moscow, 518 p.

Botalov, S.G. "Historical and cultural horizons of the Early Iron Age and the Middle Ages in the foreststeppe Trans-Urals", Arheologiya Yuzhnogo Urala. Les, lesostep. Rannij zheleznyj vek i srednevekove (problemy kulturogeneza) ("Archeology of the Southern Urals. Forest, forest-steppe. The Early Iron Age and the Middle Ages (problems of the cultural genesis)"). Chelyabinsk, 2016, pp. 468-541. (In Russ.)

Vasina, Y.V., Tairov,A.D. 2016, "Rock sanctuary at the lake Travakul", Vestnik YUUrGU. Seriya «Social'no-gumanitarnye nauki», vol. 16, no. 3, pp. 13-20. (In Russ.) doi: 10.14529/ssh160302.

Vahrushev, G.V., 1960, Mysteries of the Kapova cave (Shulgan). BFAN SSSR, Ufa, 29 p. (In Russ.)

Garustovich, G.N. 2010, Cups from the heads of the enemies", Rodina, pp. 16-20. (In Russ.)

Garustovich, G.N., Savelev, N.S. 2004, "Studies of the Bronze Age - the Early Iron Age sites in the mountain course of the Belaya river (on the problem of the cultural relicts of the Southern Urals)", Ufa Archaeological Herald, vol. 5, pp. 93-118. (In Russ.)

Herodotus, 1999, History. In 9 volumes. Ladomir, AST, Moscow, 752 p. (In Russ.)

Gimranov,D.O. "Bone remains of Holocene mammals from the Shulgan-Tash cave (excavated in 2009)", Materialy region. nauch. konf. "Arheologiya v BashGU: Itogi i perspektivy», posvyashch. 50-letiyu arheologicheskoj ekspedicii BGU ("Proceedings of the regional scientific conference "Archaeology at the Bashkir State University: results and prospects", dedicated to the 50th anniversary of the BSU archaeological expedition"). Ufa, 2011, pp. 70-73. (In Russ.)

Gorbunov, V.S., Obydennov, M.F. 1980, "Barrow necropolis of the Late Bronze Age in the Southern Bashkiria", Sovetskaya arheologiya, no.3, pp. 173-182. (In Russ.)

Savelev, N.S., Kotov, V.G., Ovsyannikov, V.V., Rumyantsev, M.M., Ruslanov,E.V., Akhmetova,E.A. 2018, Antiquities of the Bashkir Urals. Informreklama, Ufa, 216 p. (In Russ.)

Epimahov,A.V., Petrov, F.N. 2021, "Radiocarbon chronology of the Bronze Age cultural traditions in the Trans-Urals: based on the assemblages from the settlement of Levoberezhnoye (Sintashta II)", Russian Archaeology, no. 3, pp. 67-79. (In Russ.)

Zhitenev, V.S. "Anthropological assemblages from the Southern Ural cave sites with wall paintings: the problem statement" Paleolit i mezolit Vostochnoj Evropy ("Paleolithic and Mesolithic in Eastern Europe"). Moscow, 2011, pp.462-476. (In Russ.)

Zhitenev, V.S. "Kapova cave - a multi-layered archaeological site: preliminary report" Pervobytnye drevnosti Evrazii. K 60-letiyu Alekseya Nikolaevicha Sorokina ("Prehistoric artefacts of Eurasia. To the $60^{\text {th }}$ anniversary of birth of Alexei Nikolayevich Sorokin"). Moscow, 2012, pp. 155-178. (In Russ.)

Zhitenev V.S. 2014, "Arheologicheskij kontekst otkrytiya paleoantropologicheskih materialov v pachke golocenovyh naplastovanij Kapovoj peshchery", Vestnik Moskovskogo universiteta, vol.23, no. 2, pp. 114-121. (In Russ.)

Zhitenev, V.S. 2017, Kapova cave - the Upper Paleolithic cave sanctuary with wall paintings. Dissertation for the degree of Doctor of Historical Sciences. Moscow, 441 p. (In Russ.)

Zubov, S.E. 2007, "Kipchakovo cultural and chronological horizon in the system of the Pyany Bor culture", Ufa Archaeological Herald, vol.6-7, pp. 72-88. (In Russ.)

Korochkova, O.N. 2009, "On the West Siberian ash-pits of the Late Bronze Age", Russian Archaeology, № 1, pp. 25-35. (In Russ.)

Kosincev, P.A. 1992, "Remains of large mammals from the caves in the upper reaches of the Sim river", Petrin V.T. Paleoliticheskoe svyatilishche v Ignatievskoj peshchere na Yuzhnom Urale ("Petrin V.T. Paleolithic sanctuary at the Ignatievskaya cave in the Southern Urals"). Novosibirsk, 1992, pp. 178-188. (In Russ.) 
Kosincev, P.A. 2003, “Archaeozoological assemblages from the excavations of the Tashmurunovsky grotto in the upper reaches of the Belaya river", Ufa Archaeological Herald, vol. 4, pp. 148-162. (In Russ.)

Kotov, V.G. 1997, Mythology of the Southern Urals (On the question of the reconstruction of chthonic cults). Gilem, Ufa, 65 p. (In Russ.)

Kotov, V.G. 2006, Bashkir epic "Ural-Batyr". Historical and mythological origins. Gilem, Ufa, 408 p. (In Russ.)

Kotov, V.G. "Phenomenon of the Shulgan-Tash (Kapova) cave, Kulturnoe nasledie Yuzhnogo Urala kak innovacionnyj resurs. Materialy Vseros. nauch.prakt. konf. "Prirodnoe i kul'turnoe nasledie Yuzhnogo Urala kak innovacionnyj resurs" ("Cultural heritage of the Southern Urals as a source of innovations. Materials of the all-Russian scientific and practical conference "Natural and cultural heritage of the Southern Urals as a source of innovations"). Ufa, 2010, pp. 43-69. (In Russ.)

Kotov, V.G. Scientific report on the exploration of the Shulgan-Tash (Kapova) cave in the Burzyansky district of the Republic of Bashkortostan in 2009. Ufa, 2010 (In Russ.)

Kotov, V.G. "Shulgan-Tash (Kapova) cave sanctuary: structure, traces of rituals, semantics of images", Drevnie svyatilishcha: arheologiya, ritual, mifologiya ("Ancient sanctuaries: archeology, rituals, mythology"). Ufa, 2016, pp.41-63. (In Russ.)

Kotov, V.G. Scientific report on the exploration of the Shulgan-Tash (Kapova) cave in the Burzyansky district of the Republic of Bashkortostan in 2015. Ufa, 2017 (In Russ.)

Kotov, V.G. Scientific report on the exploration of the Shulgan-Tash (Kapova) cave in the Burzyansky district of the Republic of Bashkortostan according to the permit no. 1361 dated by July 31, 2017. Ufa, 2019 (In Russ.)

Kotov, V.G. Scientific report on the study of the object of cultural heritage of federal significance "Kapova cave with paintings of the Paleolithic era" according the permit no. 1041-2020 dated by 16.07. 2020 in Burzyansky district of the Republic of Bashkortostan in 2020. Ufa, 2021 (In Russ.)

Kotov, V.G., Savelev, N.S. 2003, "Fishing settlement "Tashmurunovsky grotto" in the upper reaches of the Belaya river", Ufa Archaeological Herald, vol. 4, pp. 124-147. (In Russ.)

Lyganov,A.V., Morozov, V.V., \& Azarov, E.S. 2019, "Lugovskoe I and II sites and the problem of correlation between Cherkaskul, Lugovskaya and Mezhovskaya cultures in the Lower Kama region", Archaeology of the Eurasian steppes, no. 2, pp.38-98. (In Russ.)

Lyakhnitsky,Y.S. "Long-term studies of the Shulgan-Tash (Kapova) cave by the RGRI and RGS groups as the basis of the reservation of its Paleolithic paintings", Izuchenie zapovednoj prirody Yuzhnogo Urala ("Research of the reserved nature of the Southern Urals”). Ufa, 2006, pp. 331-382. (In Russ.)

Mazhitov, N.A., Pshenichnyuk,A.H. "Barrows of the early Sarmatian culture in the Southern and
Southeastern Bashkiria", Issledovaniya po arheologii Yuzhnogo Urala ("Research in the archeology of the Southern Urals'). Ufa, 1977, pp. 52-56. (In Russ.)

Obydennov, M.F. 1998, The Mezhovskaya culture. BEK, Ufa, 201 p. (In Russ.)

Pererva, E.V., Lukyashko, S.I. "On the semantics of the scalping rite among the early Sarmatians", Pogrebal'nyj obryad rannih kochevnikov Evrazii ("Burial rite of the early nomads of Eurasia"). Rostovna-Donu, 2011, pp. 193-200. (In Russ.)

Petrin, V.T. 1992, Paleolithic sanctuary at the Ignatievskaya cave in the Southern Urals. Nauka, Novosibirsk, 207 p. (In Russ.)

Petrin, V.T., Shirokov, V.N., \& Chairkin, S.E., "Ancient sanctuary at the 2nd Serpievskaya cave in the Southern Urals", Semantika drevnih obrazov (Pervobytnoe iskusstvo) ("Semantics of ancient images. Prehistoric art"). Novosibirsk, 1990, pp.7-20. (In Russ.)

Kotov, V.G., Grigoriev, N.N., \& Devlet, E.G., Kosarev, M.N., Lyakhnitsky, Y.S., Pakhunov,A.S., Rumyantsev, M.M., Saifullina, N.M., Chervyatsova, O.Y., Shchelinsky, V.E. 2019, Cave sanctuary Shulgan-Tash (Kapova). Kitap, Ufa, 360 p. (In Russ.)

Propp, V.Y. 1986, Historical roots of the fairy tale. LGU, Leningrad, 365 p. (In Russ.)

Pshenichnyuk, A.H. 1983, The culture of the early nomads of the Southern Urals. Nauka, Moscow, 200 p. (In Russ.)

Ruslanov,E.V. "Arhcaeological sites of the Late Bronze Age in the Beregovsky archaeological microdistrict", Etnicheskie vzaimodejstviya na Yuzhnom Urale ("Ethnic interactions in the Southern Urals"). Chelyabinsk, 2015, pp.181-186. (In Russ.)

Ruslanov,E.V. "The settlement of Yumaguzino-1", Drevnosti Bashkirskogo Urala ("Antiquities of the Bashkir Urals region: a collective monograph"). Ufa, 2018, pp. 161-163. (In Russ.)

Rychkov, P.I. "Description of the cave, located in the Orenburg province near the Belaya river, which of all caves in Bashkiria is the most glorious and most revered", Issledovateli-puteshestvenniki o Bashkortostane. XVIII v. ("Explorers-travelers about Bashkortostan. The $18^{\text {th }}$ century"). Ufa, 2007, pp. 15-26. (In Russ.)

Savelev, N.S. "Mountains of the Southern Urals in the Early Iron Age", Etnicheskie vzaimodejstviya na Yuzhnom Urale ("Ethnic interactions in the Southern Urals"). Chelyabinsk, 2004, pp. 119-122. (In Russ.)

Savelev, N.S. "Archaeological sites of the Early Iron Age of the mountain course of the Belaya river (exploration work by A.P. Shokurov 1961-1962)", Nasledie vekov ("Heritage of the centuries"). Ufa, 2011, pp.42-70. (In Russ.)

Savelev, N.S. 2015, "Nomadic settlements of the Scythian-Sarmatian times in the southern part of the mountain-forest zone of the Southern Urals", Ufa Archaeological Herald, vol. 15, pp.62-84. (In Russ.)

Savelev, N.S. 2018, "Sites of the Gamayun and Kurmantau cultures in the Southwestern tip of the Ural mountain chain", Ufa Archaeological Herald, vol. 18, pp. 24-42. (In Russ.) doi: 10.31833/uav.2018.18.003. 
Serikov,Y.B. 2013, The Shaitan lake - a sacred lake of antiquity. NTGSPA, Nijniy Tagil, $408 \mathrm{p}$. (In Russ.)

Sokolov, D., Zanevskij, I., \& Simon, F. “A report on the inspection and measurement of the Kapova cave at the Belaya river in the Orsk district of the Orenburg province, near the village of Shulganova (Adilgareyeva) of the 3rd Burzyansk area", Izvestiya Orenburgskogo otdeleniya Russkogo geograficheskogo obshchestva ("Proceedings of the Orenburg branch of the Russian Geographical Society"). Orenburg, 1897, pp. 75-79. (In Russ.)

Gorbunov, V.S., Obydennov, M.F., \& Muravkina, L.I., Obydenova, G.T., Garustovich, G.N. 2001, Tyubyak: the Bronze Age settlement in the Southern Urals. BGPU, Ufa, 159 p. (In Russ.)

Chikisheva, T.A. "Anthropological remains from the Ignatievskaya cave", Petrin V.T. Paleoliticheskoe svyatilishche v Ignatievskoj peshchere na Yuzhnom Urale ("Petrin V.T. Paleolithic sanctuary at the Ignatievskaya cave in the Southern Urals"). Novosibirsk, 1992, pp. 197-198. (In Russ.)

Shorin,A.F., "Archaeological materials of the late periods (The Bronze Age - The Middle Ages) from the Ignatievskaya cave", Petrin V.T. Paleoliticheskoe svyatilishche $v$ Ignatievskoj peshchere na Yuzhnom Urale ("Petrin V.T. Paleolithic sanctuary at the Ignatievskaya cave in the Southern Urals"). Novosibirsk, 1992, pp. 198-205. (In Russ.)

Shchelinsky, V.E., "Paleogeographic environment and the archaeological assemblage of the Upper Paleolithic sanctuary of the Shulgan-Tash (Kapova) cave", Peshchernyj paleolit Urala ("Cave Paleolithic of the Urals"). Ufa, 1997, pp. 29-38. (In Russ.)

Yusupov, R.M., Nechvaloda, A.I. "On the discovery of a human skull in the Shulgan-Tash cave", Kulturnoe nasledie Yuzhnogo Urala kak innovacionnyj resurs ("Cultural heritage of the Southern Urals as a source of innovations. Materials of the all-Russian scientific and practical conference "Natural and cultural heritage of the Southern Urals as a source of innovations"). Ufa, 2010, pp. 107-115. (In Russ.)

Ščelinskij, V.E., Šsirokov, V.N. 1999, Höhlenmalerei im Ural: Kapova und Ignatievka; die altsteinzeitlichen Bilderhohlen im sudlichen Ural. Jan Thorbecke Verlag, Sigmaringen, 171 p. (In Germ.)

\section{Сведения об авторах}

Котов Вячеслав Георгиевич, кандидат исторических наук, старший научный сотрудник, Институт истории, языка и литературы Уфимского федерального исследовательского центра Российской академии наук, Российская Федерация, г. Уфа. E-mail: kslav1@yandex.ru, ORCID: 0000-0002-3510-0058

Савельев Никита Сергеевич, кандидат исторических наук, доцент, ведущий научный сотрудник, Институт истории, языка и литературы Уфимского федерального исследовательского центра Российской академии наук, Российская Федерация, г. Уфа. E-mail: sns_1971@mail.ru, ORCID: 0000-0002-3643238

\section{Information About the Authors}

Vyacheslav G. Kotov, Ph.D., senior researcher, Institute of History, Language and Literature of the Ufa Federal Research Center of the Russian Academy of Sciences, Russian Federation, Ufa. E-mail: kslav1@yandex.ru, ORCID: 0000-0002-3510-0058

Nikita S. Savelev, Ph.D., Associate Professor, leading researcher, Institute of History, Language and Literature of the Ufa Federal Research Center of the Russian Academy of Sciences, Russian Federation, Ufa. Email: sns_1971@mail.ru, ORCID: 0000-0002-3643-2388 